\title{
Impact of lightning-NO on eastern United States photochemistry during the summer of 2006 as determined using the CMAQ model
}

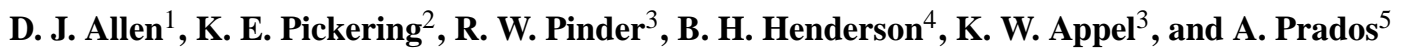 \\ ${ }^{1}$ Department of Atmospheric and Oceanic Science, University of Maryland, College Park, MD, USA \\ ${ }^{2}$ Atmospheric Chemistry and Dynamics Laboratory, Code 614 NASA-Goddard, Greenbelt, MD, USA \\ ${ }^{3}$ Atmospheric Modeling and Analysis Division, US EPA, Research Triangle Park, NC, USA \\ ${ }^{4}$ University of North Carolina Chapel Hill, NC, USA \\ ${ }^{5}$ Joint Center for Earth Sciences Technology (JCET), University of Maryland Baltimore County, Baltimore, MD, USA \\ Correspondence to: D. J. Allen (allen@atmos.umd.edu)
}

Received: 2 May 2011 - Published in Atmos. Chem. Phys. Discuss.: 23 June 2011

Revised: 22 December 2011 - Accepted: 5 February 2012 - Published: 16 February 2012

\begin{abstract}
A lightning-nitrogen oxide (NO) algorithm is implemented in the Community Multiscale Air Quality Model (CMAQ) and used to evaluate the impact of lightning-NO emissions $\left(\mathrm{LNO}_{\mathrm{x}}\right)$ on tropospheric photochemistry over the United States during the summer of 2006.
\end{abstract}

For a 500 mole per flash lightning-NO source, the mean summertime tropospheric $\mathrm{NO}_{2}$ column agrees with satelliteretrieved columns to within -5 to $+13 \%$. Temporal fluctuations in the column are moderately well simulated; however, the addition of $\mathrm{LNO}_{\mathrm{x}}$ does not lead to a better simulation of day-to-day variability. The contribution of lightning-NO to the model column ranges from $\sim 10 \%$ in the northern US to $>45 \%$ in the south-central and southeastern US. Lightning$\mathrm{NO}$ adds up to $20 \mathrm{ppbv}$ to upper tropospheric model ozone and $1.5-4.5 \mathrm{ppbv}$ to 8 -h maximum surface layer ozone, although, on average, the contribution of $\mathrm{LNO}_{\mathrm{x}}$ to model surface ozone is $1-2$ ppbv less on poor air quality days. $\mathrm{LNO}_{\mathrm{x}}$ increases wet deposition of oxidized nitrogen by $43 \%$ and total deposition of nitrogen by $10 \%$. This additional deposition reduces the mean magnitude of the CMAQ low-bias in nitrate wet deposition with respect to National Atmospheric Deposition monitors to near zero.

Differences in urban/rural biases between model and satellite-retrieved $\mathrm{NO}_{2}$ columns were examined to identify possible problems in model chemistry and/or transport. CMAQ columns were too large over urban areas. Biases at other locations were minor after accounting for the impacts of lightning-NO emissions and the averaging kernel on model columns.

In order to obtain an upper bound on the contribution of uncertainties in $\mathrm{NO}_{\mathrm{y}}$ chemistry to upper tropospheric $\mathrm{NO}_{\mathrm{x}}$ low biases, sensitivity calculations with updated chemistry were run for the time period of the Intercontinental Chemical
Transport Experiment (INTEX-A) field campaign (summer 2004). After adjusting for possible interferences in $\mathrm{NO}_{2}$ measurements and averaging over the entire campaign, these updates reduced 7-9 km biases from 32 to $17 \%$ and $9-12 \mathrm{~km}$ biases from 57 to $46 \%$. While these changes lead to better agreement, a considerable unexplained $\mathrm{NO}_{2}$ low-bias remains in the uppermost troposphere.

\section{Introduction}

Production of nitric oxide (NO) by lightning $\left(\mathrm{LNO}_{\mathrm{x}}\right)$ is an important part of the summertime tropospheric reactive odd nitrogen $\left(\mathrm{NO}_{\mathrm{x}}=\mathrm{NO}+\right.$ nitrogen dioxide $\left.\left(\mathrm{NO}_{2}\right)\right)$ budget over the United States, but it is also its most uncertain component. Globally, the $\mathrm{LNO}_{\mathrm{x}}$ source is thought to be in the range of 2 $8 \mathrm{Tg} \mathrm{N} \mathrm{yr}^{-1}$ (Schumann and Huntrieser, 2007). Global model simulations indicate that $\mathrm{LNO}_{\mathrm{x}}$ increases summertime upper tropospheric $\mathrm{NO}_{\mathrm{x}}$ concentrations over the eastern United States by $60-75 \%$, upper tropospheric ozone amounts by $15-25 \%$, and surface ozone concentrations by several ppbv (Zhang et al., 2003; Cooper et al., 2006, 2007; Allen et al., 2010).

Singh et al. (2007) found unexpectedly large amounts of $\mathrm{NO}_{\mathrm{x}}$ in the upper troposphere during the Intercontinental Chemical Transport Experiment (INTEX-A) field campaign. With few exceptions, modelers have been unable to reproduce these high $\mathrm{NO}_{\mathrm{x}}$ amounts, although increasing the midlatitude lightning-NO source reduces biases (Hudman et al., 2007; Pierce et al., 2007; Bousserez et al., 2007; Choi et al., 2008; Fang et al., 2010; Allen et al., 2010).

While the potential importance of lightning-NO emissions on regional air quality has been recognized for nearly twenty 
years (e.g. Novak and Pierce, 1993), lightning-NO emissions have only been added to regional chemistry and transport models during the last few years (e.g. Kaynak et al., 2008; Smith and Mueller, 2010; Koo et al., 2010). The addition of $\mathrm{LNO}_{\mathrm{x}}$ was a relatively low priority because most regional models were developed to serve the air quality community and upper tropospheric processes were considered secondary in importance. However, Napelenok et al. (2008) found that low-biases in upper tropospheric $\mathrm{NO}_{\mathrm{x}}$ in Community Multiscale Air Quality Model (CMAQ) (Byun and Schere, 2006) simulations without lightning-NO emissions made it difficult to constrain ground-level $\mathrm{NO}_{\mathrm{x}}$ emissions using inverse methods and Scanning Imaging Absorption Spectrometer for Atmospheric Cartography (SCIAMACHY) (Bovensmann et al., 1999; Sioris et al., 2004; Richter et al., 2005) $\mathrm{NO}_{2}$ retrievals. They also found that wet deposition of nitric acid $\left(\mathrm{HNO}_{3}\right)$ at National Atmospheric Deposition Program (NADP) sites was underestimated by a factor of two when $\mathrm{LNO}_{\mathrm{x}}$ was not included.

Here, the lightning-NO parameterization of Allen et al. (2010) is adapted for use in CMAQ. This module is expected to be available in the next release of CMAQ. This scheme is similar to the schemes of Kaynak et al. (2008), Smith and Mueller (2010), and Koo et al. (2010) in that it uses flash rates from the National Lightning Detection Network (NLDN) (Orville et al., 2002) to constrain lightningNO emissions. This scheme is similar to Koo et al. (2010) in that it places lightning-NO emissions at the locations of model convection. It differs in its vertical partitioning and also because it scales the emissions locally so that monthly average flash rates in each grid cell match NLDN observed flash rates after adjusting for climatological IC/CG ratios.

As part of the evaluation of this scheme, CMAQ simulations with and without lightning-NO production are used to estimate the contribution of lightning-NO to upper tropospheric photochemistry, surface air quality, and nitrogen deposition over the continental United States for the summer of 2006. The evaluation is the first to use detailed comparisons with in situ and space-based measurements. Finally, in order to obtain an upper bound on the contribution of uncertainties in $\mathrm{NO}_{\mathrm{y}}$ chemistry to upper tropospheric $\mathrm{NO}_{\mathrm{x}}$ low biases, sensitivity calculations with updated chemistry were run for the time period of the INTEX-A field campaign (summer 2004) in order to determine if lightning-NO and recent improvements in our understanding of $\mathrm{NO}_{\mathrm{y}}$ chemistry can lead to a better simulation of the upper tropospheric $\mathrm{NO}_{\mathrm{x}}$ concentrations measured during INTEX-A.

\section{Observations and model}

\section{1 $\mathrm{NO}_{2}$ column products from $\mathrm{OMI}$}

The Ozone Monitoring Instrument (OMI) aboard the NASA Aura satellite (launched 15 July 2004) measures direct- and back-scattered sunlight in the ultraviolet-visible range. It retrieves $\mathrm{NO}_{2}$ with a resolution of up to $13 \mathrm{~km} \times 24 \mathrm{~km}$. Two tropospheric $\mathrm{NO}_{2}$ products are used in this study. These products are the DOMINO product (Boersma et al., 2007, 2011) and the DOMINO/GEOS-Chem product (DP-GC) (Lamsal et al., 2010). These products use the same slant column and the same approach for separation of the stratospheric column from the tropospheric column. They differ in their calculation of the tropospheric air mass factor. These differences lead to substantially different tropospheric column amounts (e.g. Bucsela et al., 2008; Lamsal et al., 2010; Herron-Thorpe et al., 2010). Version 2.0 (Boersma et al., 2011) of the DOMINO product is used in this study. The DPGC product differs from version 1.0.2 of the DOMINO product in that it uses cross-track bias corrected slant columns and calculates its air mass factors using vertical profiles from the GEOS-CHEM model (Martin et al., 2003) rather than the TM4 model (Dentener et al., 2003).

Gridded $0.25^{\circ} \times 0.25^{\circ}$ DP-GC fields were obtained from Lamsal et al. (2010). Gridded DOMINO fields were created by mapping version 2.0 level 2 DOMINO fields onto the same $0.25^{\circ} \times 0.25^{\circ}$ grid. On a day-by-day basis, highquality DOMINO retrievals with fields of view that partially or totally overlap a given grid box were identified. Retrievals over snow- and ice-free surfaces with cloud radiance fractions of less than $50 \%$ were identified as high quality (Boersma et al., 2009). The mean value in each grid box was then obtained by weighting the high-quality retrievals using the algorithm of Celarier and Retscher (2009). This algorithm gives more weighting to pixels with near-nadir field of views than far-off-nadir fields of view and to clear pixels than partly cloudy pixels. Pixels with cloud geometric fractions exceeding 0.3 are given a weighting of 0 . Since lightning-NO emissions are associated with clouds, this cloud-dependent weighting could lead to a low-bias in satellite-retrieved columns. In order to minimize the impact of this effect on conclusions, CMAQ profiles are weighted in the same manner as DOMINO profiles. The mean value in each $0.25^{\circ} \times 0.25^{\circ}$ grid box was obtained by weighting the CMAQ profiles using the weights associated with their corresponding DOMINO retrievals. When appropriate, the averaging kernel was applied to tropospheric model sub-columns before the weighting was performed. Details on the averaging kernel processing are given in Allen et al. (2010) and Boersma et al. (2009).

\subsection{Ozone profiles from OMI and sondes}

Ozone profiles along the OMI orbits (level 2 products) are available from Liu et al. (2010) as a research product. These profiles are represented on 24 layers, four to six of which are in the troposphere. Several steps are required in order to compare these profiles with output from CMAQ. The first step is quality control. The OMI retrievals include fitting residuals and root mean square errors. Retrievals with 
fitting residuals exceeding 2 or root mean square (RMS) errors exceeding 1.5 are flagged as questionable and are removed from the OMI data set. In step two, CMAQ profiles are extracted at the locations and times of the remaining OMI retrievals. CMAQ output is archived hourly. The hours to extract are determined by comparing the local times at CMAQ grid boxes with the Aura satellite overpass time. In step three, these profiles are interpolated onto the OMI vertical grid and converted to Dobson Units. In step four, CMAQ ozone amounts in OMI layers above the CMAQ model top $(50 \mathrm{hPa})$ are set to the OMI a priori. This step is for convenience only and does not impact the ultimate tropospheric column. In step five, OMI averaging kernels are applied to the CMAQ profiles. In step six, layers within the troposphere are summed to obtain tropospheric columns for each OMI pixel. The OMI tropopause pressure and the number of OMI layers within the troposphere are contained in the OMI data set. The OMI data sets are constructed so that no layer spans the tropopause. The result of these steps is an estimate of the CMAQ tropospheric column at the locations of OMI retrievals. In step 7, retrievals with cloud fractions exceeding a threshold (50\% here) are removed. The remaining OMI and CMAQ columns for each day are then aggregated onto a $0.5^{\circ} \times 0.5^{\circ}$ grid. Each pixel is only assigned to one grid box using the longitude and latitude at the center of the OMI pixel.

During the summers of 2004 and 2006 as part of the INTEX Ozonesonde Network (IONS), several hundred ozonesondes were launched from North American sites including Boulder, CO; Houston, TX; Huntsville, AL; and Wallops Island, VA (Thompson et al., 2007a, b). Ozone profiles from these sondes will be compared to CMAQ profiles from the same time.

\subsection{CMAQ model and simulations}

The 2006 simulation without lightning-NO emissions was performed as part of the Air Quality Model Evaluation International Initiative (AQMEII) (Rao et al., 2010), while the 2006 simulation with lightning-NO emissions was specially performed for the work described in this paper. Both simulations were performed with CMAQ version 4.7.1, Carbon Bond 2005 (CB-05) chemical mechanism, and AERO5 aerosol module. The model domain included all of the continental United States at $12 \mathrm{~km}$ horizontal resolution (459 longitudes by 299 latitudes) with 34 vertical layers from the surface to the $50 \mathrm{hPa}$ model top. Approximately 12 model layers are in the lowest $1-\mathrm{km}$ of the atmosphere. Meteorological fields were obtained from a year-long simulation with version 3.1 of the Weather Research and Forecasting Model (WRF) (Skamarock et al., 2005) with the Kain-Fritsch convective parameterization (Kain and Fritsch, 1993). The emissions included data from point sources equipped with continuous emissions monitoring systems (CEMs) that measure sulfur dioxide $\left(\mathrm{SO}_{2}\right)$ and $\mathrm{NO}_{\mathrm{x}}$ emission rates and other parameters daily, mobile emissions processed by the Mobile6 model, and meteorologically adjusted biogenic emissions from the Biogenic Emission Inventory System (BEIS) (Vukovich and Pierce, 2002) 3.14, all specific for the year 2006. All other emissions are from the National Emission Inventory 2005 version 2, scaled to represent year 2006 (http: //www.epa.gov/ttnchie1/emch/). The emissions were chemically speciated, and temporally and spatially allocated using Sparse Matrix Operator Emissions (SMOKE) version 2.6 (SMOKE et al., 2009). Temporally varying chemical boundary conditions are from the Global and regional Earth-system (Atmosphere) Monitoring using Satellite and in-situ data (GEMS) (Hollingsworth et al., 2008). The GEMS data are reported every three hours and are interpolated to hourly values for CMAQ. The 2006 simulations were initialized on 22 December 2005 and run through 31 December 2006. The first 10 days of the simulation are excluded from the analysis to remove the influence of initial conditions.

While 2006 offers the opportunity to compare with surface and high-resolution satellite-based measurements, prior work has shown that CMAQ underestimates the high $\mathrm{NO}_{\mathrm{x}}$ concentrations measured in the upper troposphere during INTEX-A in 2004 (Napelenok et al., 2008). Accordingly, in addition to the 2006 simulation described above, the summer of 2004 CMAQ simulations described by Napelenok et al. (2008) are revisited to better understand $\mathrm{NO}_{\mathrm{x}}$ in the upper troposphere. For consistency, these simulations use the same modeling domain. It includes the continental United States at $36 \mathrm{~km}$ horizontal resolution with 24 vertical layers. Meteorological fields were developed using the fifth generation mesoscale model (MM5) version 3.6.3 (Grell et al., 1995). The emissions are developed for year 2004 using the same data sources as described above; details are available in Gilliland et al. (2008). To take advantage of recent developments relevant to the upper troposphere, we use CMAQv4.7.1 with CB-05 chemistry and AERO5 aerosols. Boundary conditions are derived from a GEOS-Chem (Bey et al., 2001) simulation and are spatially variable, but constant in time. Upper tropospheric ozone amounts in the 2004 boundary conditions are capped at 75 ppbv. The 2004 simulations were initialized on 21 May 2004 and run through 30 August 2004. The first ten days of the simulation are excluded from the analysis to remove the influence of initial conditions.

\subsubsection{Specification of lightning-NO source in CMAQ}

CMAQ requires emissions as a function of time and space. The lightning $\mathrm{NO}$ source $\left(\mathrm{LNO}_{\mathrm{x}}\right)$ was parameterized in terms of the flash frequency (LF), flash energy $(E)$, and the NO production per unit energy $(P)$. Symbolically,

$\mathrm{LNO}_{\mathrm{x}}=k \cdot \mathrm{LF} \cdot E \cdot P$,

where $k$ is a conversion factor equal to the molecular weight of nitrogen $(\mathrm{N})$ divided by Avogadro's number. Implicit in 
this equation is the assumption that intracloud (IC) flashes are as energetic as cloud-to-ground (CG) flashes. The flash energy associated with CG and IC flashes has been the subject of much recent research. Recent midlatitude and subtropical storm-scale case studies involving cloudresolved modeling constrained by observed flash rates and anvil $\mathrm{NO}_{\mathrm{x}}$ measurements from field experiments such as STERAO (DeCaria et al., 2005), CRYSTAL-FACE (Ott et al., 2007); and EULINOX (Fehr et al., 2004) have found that IC flashes are approximately as energetic as CG flashes and that both CG and IC midlatitude flashes produce approximately 500 moles of $\mathrm{N}$ per flash on average (Ott et al., 2010). This value is on the higher end of estimates in Schumann and Huntriesser (2007) and is much higher than a recent topdown estimate obtained by Beirle et al. (2010) from their comparison of observed flash rates and $\mathrm{NO}_{2}$ columns from SCIAMACHY. In these CMAQ simulations, we assume all flashes produce 500 moles of $\mathrm{N}$. The $\mathrm{LNO}_{\mathrm{x}}$ algorithm we have developed for CMAQ ensures that lightning emissions are located only in grid cells in which parameterized deep convection is active. The flash frequency for each grid box is obtained by multiplying domain-wide $(D)$ and local $\left(\alpha_{\mathrm{i}, \mathrm{j}}\right)$ scaling factors by the adjusted convective precipitation rate. Symbolically,

$\mathrm{LF}_{i, j}=D \cdot \alpha_{i, j} \cdot\left(\text { precon }_{i, j}-\text { threshold }\right)^{\gamma}$,

where $i$ and $j$ are indices of individual CMAQ grid boxes, precon is the convective precipitation rate from the meteorological model at grid boxes where the convective cloud top pressure is less than $450 \mathrm{hPa}$ (i.e. deep convection), threshold is the value of precon below which the flash rate is assumed to equal zero, $D$ is a scaling factor chosen so that the domainaveraged model flash rate equals a specified value, $\alpha$ is a local adjustment factor calculated after $D$ and chosen so that the monthly average model-calculated flash rate for each grid box equals a specified value (e.g. Allen et al., 2010; Martini et al., 2011). The threshold is set to 0 for these simulations because for a pressure threshold of $450 \mathrm{hPa}$, the mean spatial coverage of deep convection in the meteorological model is less than the mean spatial coverage of lightning flashes. The value for the power $(\gamma)$ is set to one because observations over the southern United States show a weak linear relationship between flash rate and convective rainfall rate (Petersen and Rutledge, 1998; Tapia et al., 1998). Convective precipitation was chosen as the flash rate predictor because of this relationship and also because it is readily available in output streams from WRF, the meteorological model most commonly used to drive CMAQ. Tost et al. (2007) examined the performance of other possible predictors including cloud top height and updraft velocity.

Sauvage et al. (2007) and Allen et al. (2010) use timeaveraged flash rates from Optical Transient Detector and Lightning Imaging Sensor (OTD/LIS) (Mach et al., 2007) to constrain model flash rates. Martin et al. (2007) use satellite-retrieved trace gas distributions to constrain model flash rates. In this study, we follow a similar approach but use monthly average flash rates from the National Lightning Detection Network (NLDN) (Cummins et al., 1998) to constrain model flash rates. Jourdain et al. (2010) used daily average NLDN flash rates to constrain model flash rates. For these simulations the domain-wide constraint $(D)$ is chosen so that when averaged over a month, the domain-averaged flash rate calculated from Eq. (2) with $\alpha(i, j)=1$ matches the mean "observed" flash rate. The mean "observed" flash rate over the United States is obtained by mapping detection efficiency-adjusted NLDN flash rates onto the CMAQ grid and then multiplying the resulting flash rates by $Z+1$, where $Z$ is the smoothed climatological IC/CG ratio at that grid box. Unsmoothed climatological values of $Z$ are available from Boccippio et al. (2001). In order to lessen the difference between $12-\mathrm{km}$ and $36-\mathrm{km}$ local scaling factors and to partially compensate for positioning errors in the location of model convection, the $12-\mathrm{km}$ flash rates are smoothed by a $3 \times 3$ moving average before calculating $D$ and $\alpha$. NLDN detection efficiencies were obtained from the Vaisala detection efficiency model (R. Holle, personal communication, 2010) but are constrained to be between 0.1 and 0.93 , where 0.93 is the estimated detection efficiency of the NLDN over the United States during the 2004-2006 time period (Biagi et al., 2007). Flash rates at locations with NLDN detection efficiencies of $<10 \%$ are replaced by climatological flash rates from version 2.2 of the OTD/LIS climatology (Boccippio et al., 2002; Mach et al., 2007).

Local adjustment factors $\left(\alpha_{i, j}\right)$ are chosen so that when averaged over one-month periods of interest, model flash rates match observed total (sum of CG + IC) flash rates subject to the constraint that $\alpha_{i, j}$ is constrained to be between 0.1 and 10. During non-winter months, the lower constraints are invoked at approximately $7 \%$ of grid boxes within the $110^{\circ}-$ $70^{\circ} \mathrm{W} 25^{\circ}-45^{\circ} \mathrm{N}$ analysis region, while upper constraints are invoked at approximately $2 \%$ of grid boxes. Therefore, monthly average model flash rates will not exactly match "observed" flash rates. Diurnal and day-to-day fluctuations in flash rates are not constrained.

In parallel with this study, vertical profiles of lightningNO emissions for CMAQ were developed by W. Koshak of NASA-MSFC under a research project entitled: NASA Lightning Results for Improving the CMAQ Decision Tool. The 2004 simulations assume that emissions are proportional to pressure convolved by the mean April to September 20032005 vertical distribution of VHF sources from the Northern Alabama Lightning Mapping Array (Koshak et al., 2004; Hansen et al., 2010). The 2006 simulation uses more recent results from Koshak and assumes that emissions are proportional to pressure convolved by the segment altitude distribution of flashes from the same LMA (Koshak et al., 2010). With both approaches, $\mathrm{NO}_{\mathrm{x}}$ emissions are distributed in all model layers from the surface to the layer containing the convective cloud top. In practice, the difference between the approaches is small (Fig. 1) with the 2006 approach putting a 


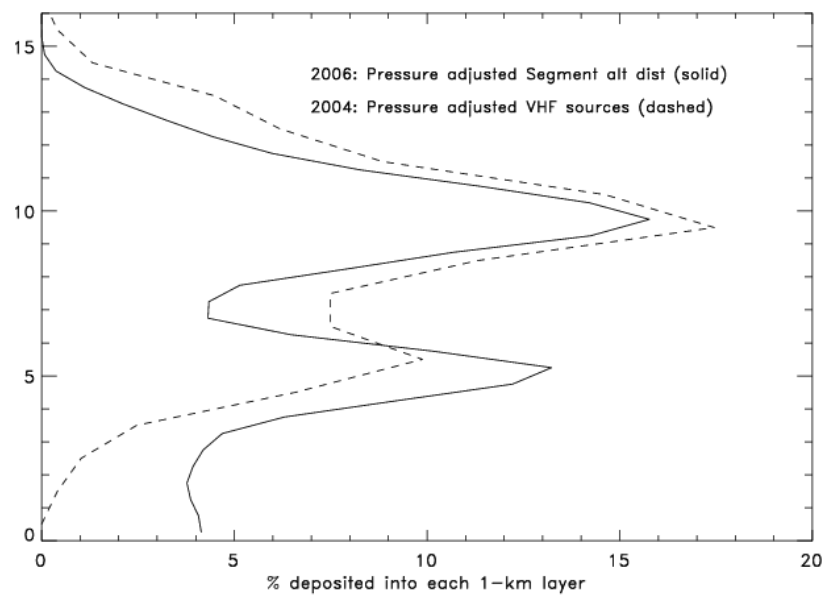

Fig. 1. Vertical distribution of lightning-NO production assumed for 2004 (dashed) and 2006 (solid) simulations. The distribution for 2004 was derived from the vertical distribution of VHF sources in the vicinity of the Northern Alabama LMA during the April to September 2003-2005 time period. The distribution for 2006 was derived from the vertical distribution of segment altitude distributions in the same area.

bit less NO near the intracloud flash generated peak in the upper troposphere and a bit more NO near the peak in the mid-troposphere.

\subsubsection{Evaluation of flash rate distribution in CMAQ}

Figure 2a-c compares model and observed 24-h average flash rates on 10 July 2006 . On this particular day, lightning is evident over much of the United States with local maxima over Oklahoma, the Great Lakes, the northeastern United States, and the western Atlantic off the coast of North Carolina. The western Atlantic peak is likely underestimated by the NLDN network as the network is land-based and detection efficiencies fall off rapidly more than $300 \mathrm{~km}$ from the coast. Model flash rates for $\alpha_{i, j}=1$ (Fig. 2b) are similar to observed flash rates although the Oklahoma maximum is shifted northward to Kansas, and the flash frequency is underestimated over the Great Lakes and northeastern United States and overestimated over the western Atlantic. Applying the local scaling factors improves the agreement with observations as flash rates are increased over Oklahoma and the Great Lakes and decreased over the western Atlantic (Fig. 2c).

In order to assess the agreement between modeled and observed flash rates, NLDN flash rates during June-August were matched with model convection. This analysis showed that when averaged over a one-hour time period $35-45 \%$ of the strikes measured by the NLDN occur within WRF grid boxes with convective precipitation. When the averaging period is increased to one day, more than $90 \%$ of the strikes occur in WRF grid boxes with convective precipitation (not shown). Figure $3 \mathrm{a}-\mathrm{d}$ summarizes the agreement between modeled and observed flash rates over the entire domain. Correlations between modeled and observed hourly flash rates average 0.70 and do not vary much from month to month ranging from 0.50 in April 2006 to 0.83 in December 2006 (Fig. 3a). The relatively small variability in hourly flash rate correlations from month-to-month masks substantial seasonal differences in how well the model captures diurnal (Fig. 3b) - and daily (Fig. 3c) - fluctuations in the hourly flash rates. Diurnal variations (each hour averaged over a month) are extremely well captured during the summer as diurnal correlations exceed 0.85 during June through September. Reasonable agreement is also seen in transition months with correlations ranging from 0.45 to 0.80 during the spring and fall. Wintertime diurnal correlations vary greatly equaling 0.82 in December, 0.31 in January, and -0.02 in February. The larger wintertime variability in monthly correlations is likely due to the weak diurnal cycle during this season and the limited number of events.

During the fall through spring, most thunderstorms occur in the warm sector in advance of a cold front. Day-to-day variations in the locations of these storms are well captured with correlations averaging 0.80 and ranging from 0.67 to 0.90 . In the summer, thunderstorms are more stochastic in nature and are difficult to model accurately. Observed and modeled daily-total flash rates are only weakly correlated during this period. The low correlations during this time period mean that the simulation of day-to-day variations in summertime upper tropospheric $\mathrm{NO}_{2}$ is unlikely to improve when lightning-NO is added to CMAQ. Day-to-day variability in flash rates is well captured during mid-fall through midspring but underestimated by approximately $30 \%$ during the summer (Fig. 3d).

Correlations between model and observed flash rates are often less than one might hope because of several factors. (1) Lightning is not always associated with convective precipitation. (2) The linear dependence of flash rate on convective precipitation rate is an oversimplification. (3) Model convective events, even when simulated, are often misplaced by a few hours or a few grid boxes. As noted before, diurnal errors are largest when diurnal forcing is weak (October-February) and day-to-day errors are largest when synoptic forcing is weak (summer).

\section{Results}

In order to determine the enhancement of tropospheric composition over the United States associated with lightningNO emissions, CMAQ (Byun and Schere, 2006) simulations with and without lightning-NO emissions were performed for the entire year of 2006. The use of zero-out simulations to examine the amount of ozone that can be attributed to lightning is not strictly accurate as ozone production is a nonlinear function of $\mathrm{NO}_{\mathrm{x}}$ concentrations (Liu et al., 1987). However, sensitivity runs have shown it is a good approach 

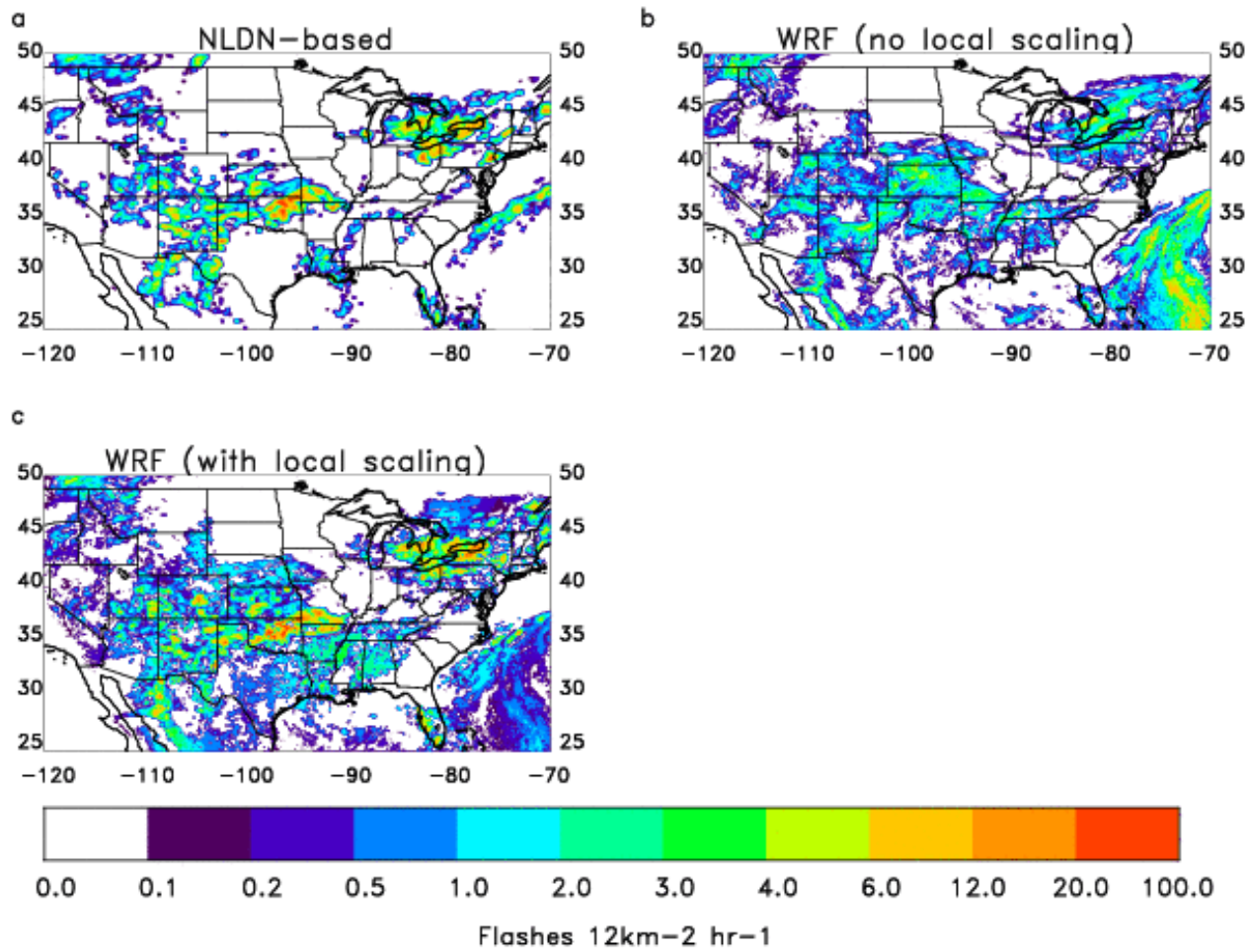

Fig. 2. Flash rate distribution on 10 July 2006. (a) NLDN-based estimate obtained by multiplying NLDN CG flash rate by $Z+1$, where $Z$ is the smoothed climatological IC/CG ratio, (b) model flash rate before applying local-scaling factors, and (c) model flash rate after applying local-scaling factors
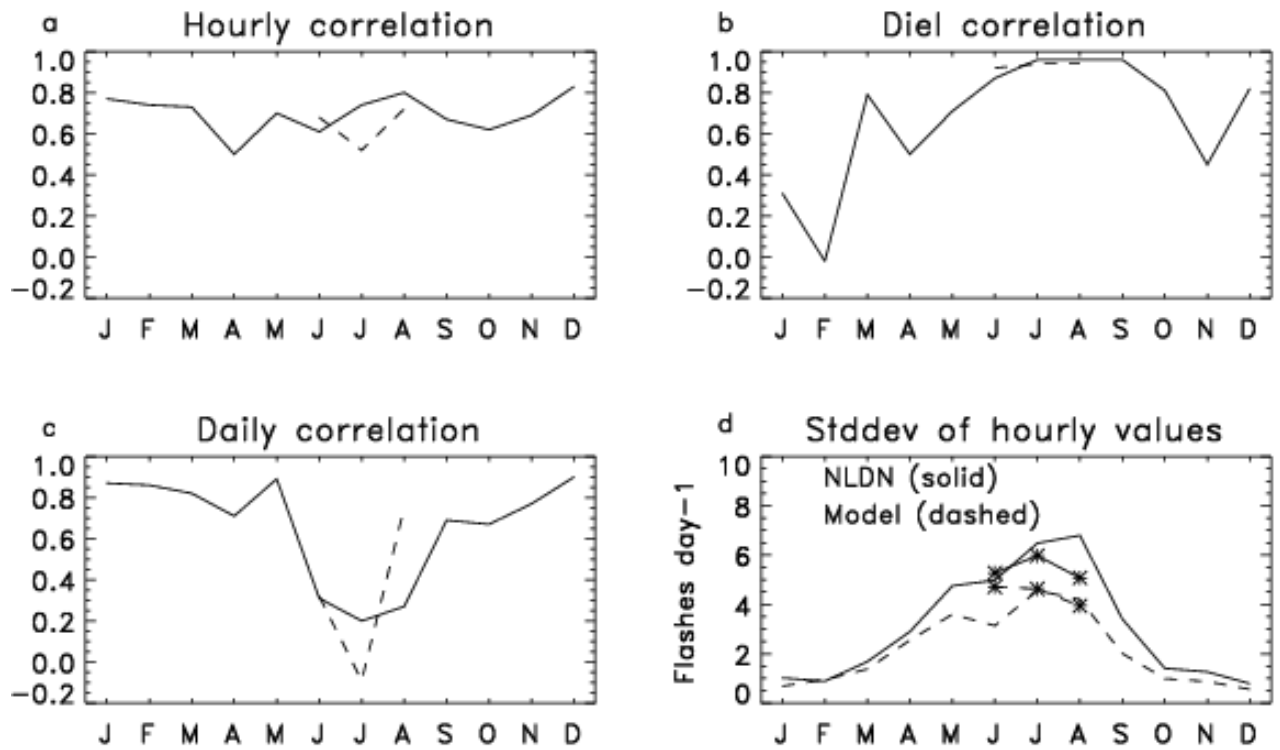

Fig. 3. Time series summarizing the agreement between model and NLDN-based total flash rates for January-December 2006 and June through August 2004. (a) Correlation between flash rates for individual hours within each month, (b) correlation between hourly flash rates after averaging out daily variations, (c) correlation between daily-total flash rates, and (d) standard deviation of model and measured hourly flash rates. For $(\mathbf{a}-\mathbf{c})$, the solid lines show 2006 and the dashed lines show 2004. For (d), the solid line shows the standard deviation of the data and the dashed line shows the standard deviation of the model; results for 2004 are identified by asterisks. 
for determining the response of ozone to $\mathrm{NO}_{\mathrm{x}}$ perturbations of less than 30-40\% (Kunkrishnan and Lawrence, 2004), and it may be the best approach for determining the amount of ozone with a lightning-NO source (e.g. Hudman et al., 2007; Sauvage et al., 2007b; Kaynak et al., 2008; and Zhao et al., 2009).

Four simulations are performed for 2004 - without lightning NO (simulation noL), with lightning NO (simulation $\mathrm{LNO}_{\mathrm{x}}$ ), with lightning $\mathrm{NO}$ and aircraft $\mathrm{NO}$ (simulation airLNO ${ }_{\mathrm{x}}$ ), and a chemistry sensitivity test with updates as recommended by Henderson et al. (2011) (simulation adjchemLNO $\mathrm{x}_{\mathrm{x}}$ ). Aircraft $\mathrm{NO}$ emissions for simulation airLNO $\mathrm{x}_{\mathrm{x}}$ are based on scheduled commercial aircraft (Baughcum et al., 1996) and military, chartered and nonscheduled jet aircraft (Metwally, 1995) emission inventories developed for the year 1992. For this chemistry sensitivity test, organic nitrate $(\mathrm{ON})$ yield from the oxidation of paraffins (PAR) was reduced from $15 \%$ to $3 \%$. In the CB-05 chemical mechanism, acetone is lumped with the paraffins. Since acetone is a major component $(\sim 75 \%)$ of PAR in the upper troposphere, this reaction should produce much less $\mathrm{ON}$. The decrease in ON production reduces NO consumption, increases the $\mathrm{NO}_{\mathrm{x}}$ lifetime, and is in better agreement with observations and other models (Henderson et al., 2011).

\subsection{Comparison with $\mathrm{NO}_{2}$ columns}

Figure 4 compares model-calculated and satellite-retrieved variations in the mean daily tropospheric $\mathrm{NO}_{2}$ column over the eastern two-thirds of the United States and adjacent western Atlantic $\left(110^{\circ}-70^{\circ} \mathrm{W}, 25^{\circ}-45^{\circ} \mathrm{N}\right)$. Model columns were created by integrating model concentrations at the hour closest to the Aura overpass (13:30 LT) from the surface to tropopause. When averaged over the entire time period, the mean averaging-kernel processed CMAQ column has a small high-bias $(11 \%)$ with respect to the mean DPGC column ( 1.33 peta molecules $\mathrm{cm}^{-2}$ ) and a small lowbias $(9 \%)$ with respect to the mean DOMINO column (1.62 peta molecules $\mathrm{cm}^{-2}$ ). Day-to-day variations in the column are sensitive to the method used to map columns onto a level 3 grid as the temporal correlation between the DOMINO and DP-GC products is only 0.29 . The correlation between CMAQ and the DOMINO product is 0.47 , while the correlation between CMAQ and the DP-GC product is a relatively robust 0.79 . The modest (but non-zero) correlations suggest that the model has some skill in capturing day-to-day variations in mean tropospheric column over the United States. For a 500 mole per flash source, lightningNO emissions on average in the summer of 2006 contributed $0.36 \times 10^{15}$ molecules $\mathrm{cm}^{-2}$ to the tropospheric column, accounting for $25 \%$ of the total model column over this region.

Figure 5a shows the model-calculated contribution of lightning-NO emissions to the mean tropospheric $\mathrm{NO}_{2}$ column during the summer of 2006. As expected, the contribution is largest over the southeastern United

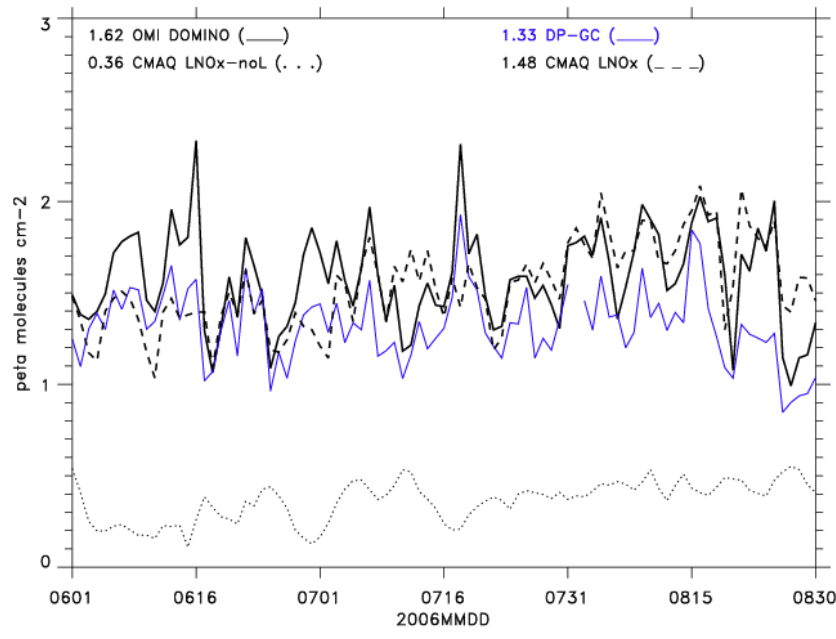

Fig. 4. Time series comparing area-averaged $\left(110^{\circ}-70^{\circ} \mathrm{W}, 25^{\circ}-\right.$ $45^{\circ} \mathrm{N}$ ) tropospheric $\mathrm{NO}_{2}$ columns for June-August 2006. Solid blue (black) line shows the mean DP-GC (version 2.0 DOMINO) column. The dashed line shows averaging-kernel processed model output from simulation $\mathrm{LNO}_{\mathrm{x}}$. The dotted line shows the contribution of lightning-NO production to the total model column (simulation $\mathrm{LNO}_{\mathrm{X}}-$ simulation noL).

States where lightning is common. Contributions exceed $0.6 \times 10^{15}$ molecules $\mathrm{cm}^{-2}$ throughout much of Florida and coastal sections of the southeast. The spatial distribution of percent contributions (Fig. 5b) is much different. It shows peaks over the southwestern United States/northwestern Mexico, the northern Gulf of Mexico, and the western Atlantic (southeast of Virginia). Figure $5 \mathrm{c}-\mathrm{d}$ shows the biases between the modeled and satellite-retrieved columns. Overall, the mean column is $5 \%$ low with respect to the DOMINO column but $13 \%$ high with respect to the DP-GC column. With the exception of urban areas, model biases over the western United States are usually negative, while biases over the southern and eastern United States are often positive, especially over extreme southern Louisiana and Florida. Over the northeastern United States, CMAQ has a low-bias with respect to the DOMINO product and a high-bias with respect to the DP-GC product.

Figure 6 compares the 1 June 2006 to 30 August 2006 mean tropospheric $\mathrm{NO}_{2}$ column from DOMINO (Fig. 6a) with three different representations of the CMAQ column from simulation $\mathrm{LNO}_{\mathrm{x}}$. Figure $6 \mathrm{~b}$ shows the mean column on the native $12-\mathrm{km}$ grid. It was calculated using model output at the hour closest to overpass time and assumes a tropopause pressure of $150 \mathrm{hPa}$. Figure $6 \mathrm{c}$ shows the mean column after mapping unprocessed CMAQ columns onto the DOMINO grid, while Fig. 6d shows the mean column after mapping averaging-kernel processed CMAQ columns onto the DOMINO grid. Several features stand out. First, application of the averaging kernel changes the mean model column but only by $8 \%$. Of course, local changes can be much larger. For example, Herron-Thorpe et al. (2010) found that 

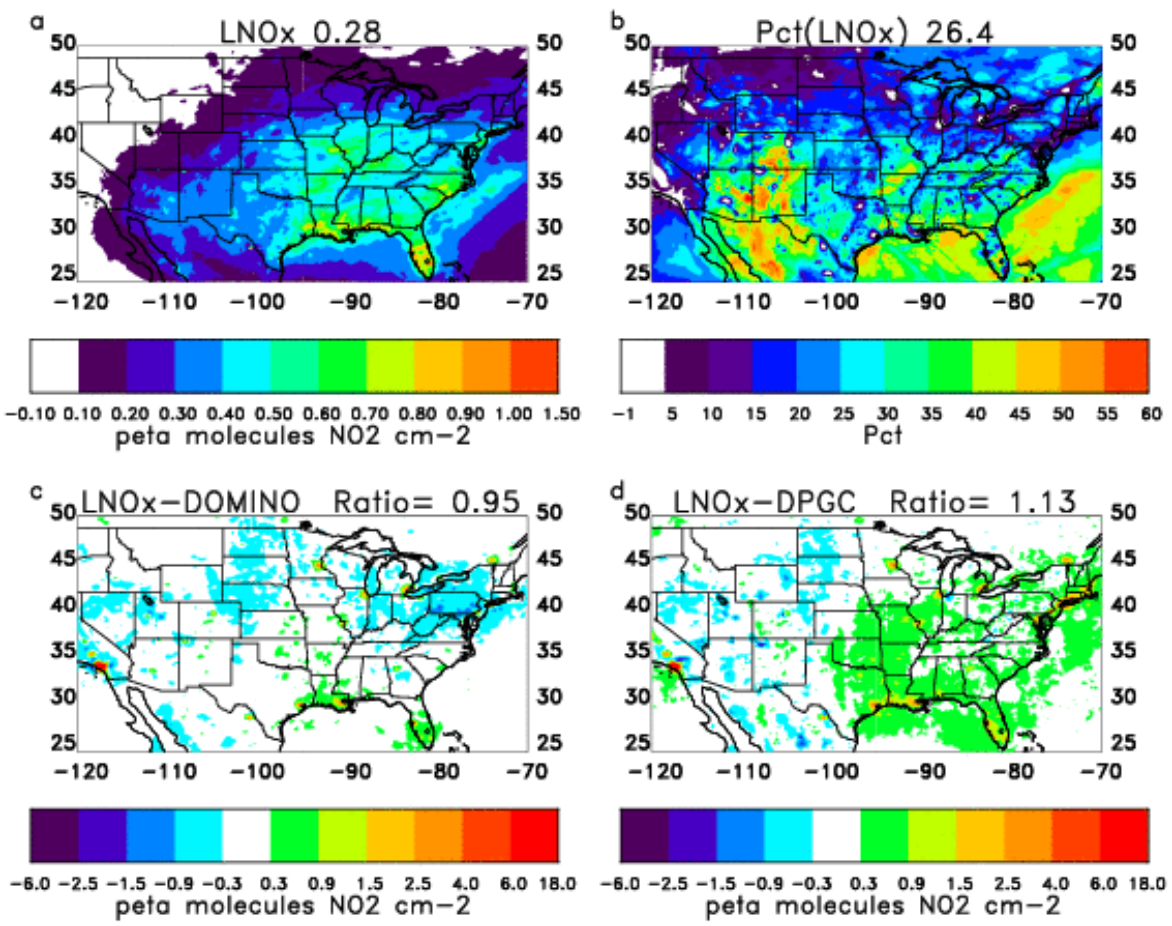

Fig. 5. Contribution of lightning-NO to mean tropospheric $\mathrm{NO}_{2}$ columns during the summer of 2006 and column biases with respect to satellite-retrieved columns. The upper left panel shows the increase in $\mathrm{NO}_{2}$ column due to $\mathrm{LNO}_{\mathrm{x}}$ (peta molecules $\mathrm{cm}^{-2}$ ). The upper right panel shows the percent of $\mathrm{NO}_{2}$ column with an $\mathrm{LNO}_{\mathrm{x}}$ source. The lower left (right) panel shows the bias between the averaging kernel processed $\mathrm{NO}_{2}$ column from simulation $\mathrm{LNO}_{\mathrm{x}}$ and the DOMINO (DP-GC) column.
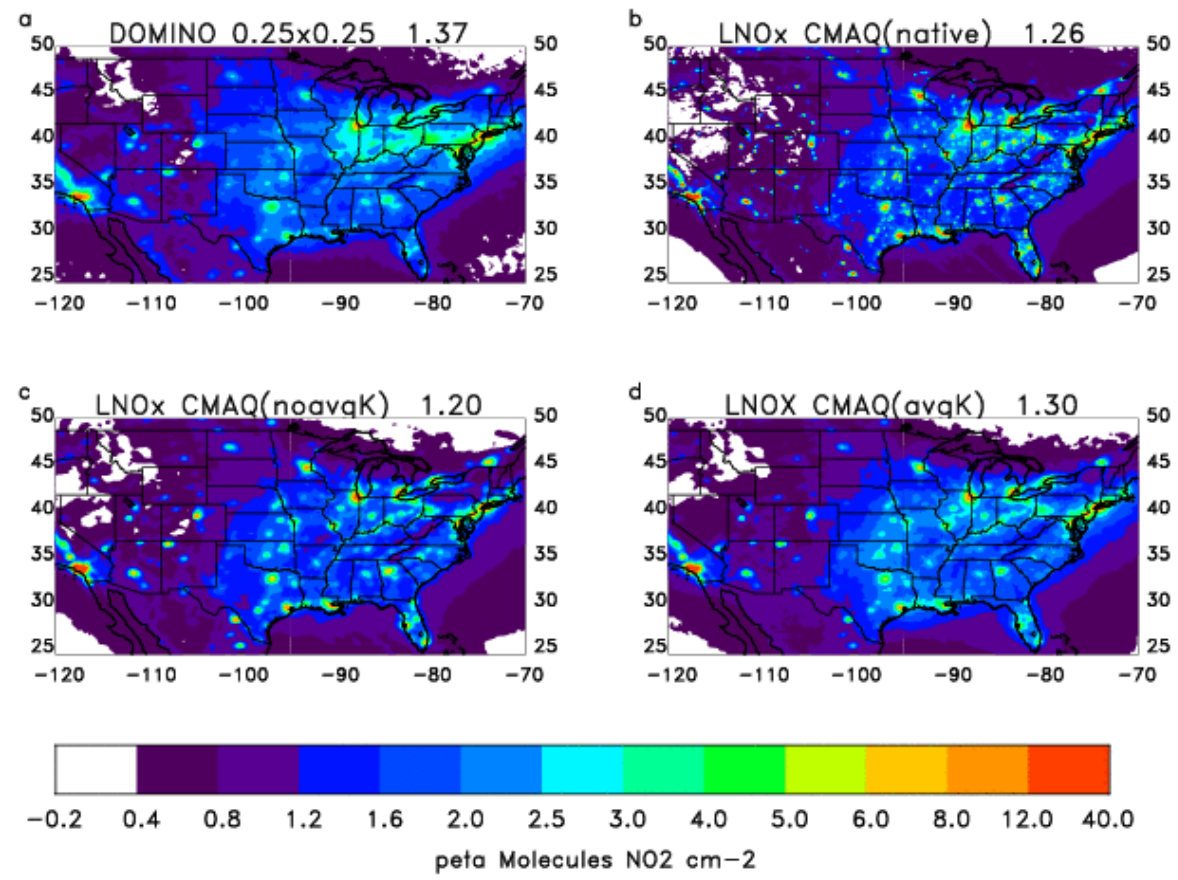

Fig. 6. Mean tropospheric $\mathrm{NO}_{2}$ column for 1 June 2006 to 30 August 2006. The upper left panel shows the mean version 2.0 DOMINO column. The upper right panel shows the mean CMAQ column from simulation $\mathrm{LNO}_{\mathrm{x}}$ on the native 12-km grid. The lower left (right) panel shows the mean CMAQ column from simulation $\mathrm{LNO}_{\mathrm{x}}$ on the $0.25^{\circ} \times 0.25^{\circ}$ DOMINO grid without (with) processing by the averaging kernel. 
application of the OMI DOMINO averaging kernel to model output reduced columns over urban areas in the northwestern United States by $35-50 \%$. Second, both mapping and averaging kernel processing smooth the columns improving the agreement with the satellite-retrieved DOMINO product that has also been mapped onto a $0.25^{\circ} \times 0.25^{\circ}$ grid.

Huijnen et al. (2010) compared tropospheric $\mathrm{NO}_{2}$ columns over Europe from ten different regional models and two global models to the DOMINO product, version 1.0.2. They found that median model columns were too low at rural locations and too high at urban locations. Castellanos et al. (2011) also found high biases at urban locations and local biases at rural locations when comparing compared CMAQcalculated $\mathrm{NO}_{\mathrm{y}}-\mathrm{HNO}_{3}$ with " $\mathrm{NO}_{2}$ " measurements at rural and urban monitoring sites over the eastern United States. These differing biases are important because they suggest that the lifetime of $\mathrm{NO}_{2}$ (see Henderson et al., 2011) and/or the transport of $\mathrm{NO}_{\mathrm{x}}$ (see Gilliland et al., 2008) is underestimated by regional models. These underestimations could lead to errors in inverse-based emissions of sources and to misleading results as to the relative importance of local versus regional emissions.

In order to investigate this possible problem in more detail, we examine how urban to rural ratios change when lightningNO emissions are set to zero, when the CMAQ output is mapped onto a $0.25^{\circ} \times 0.25^{\circ}$ grid, and when an averaging kernel is applied. The resulting ratios are compared to ratios from the DOMINO and DP-GC products. Figure 7 shows these ratios as a function of the population density threshold chosen to separate rural sites from urban sites. Population data obtained from 2000 census. Only populated United States grid boxes used when calculating the mean ratios. In general, model-calculated urban-to-rural ratios exceed satellite-retrieved ratios with differences becoming increasingly large as the minimum population density required to be classified as urban increases. The largest urban-torural ratios are seen when the analysis is performed using CMAQ output from simulation noL (e.g. 4.05 for a threshold of 100 people per $\mathrm{km}^{2}$ ). $\mathrm{NO}_{2}$ with a lightning-NO source is present over both urban and rural locations. Therefore, the addition of lightning-NO emissions to a CMAQ simulation decreases the ratios resulting in slightly better agreement with satellite-retrieved values. Ratios decrease substantially when the 12-km CMAQ output is mapped onto the $0.25^{\circ} \times 0.25^{\circ}$ DOMINO grid (e.g. 2.45 for a threshold of 100 people per $\mathrm{km}^{2}$ ) because urban grid boxes are mixed with rural grid boxes during the aggregation process. Modelcalculated ratios are lowest when calculated with averagingkernel processed output from simulation $\mathrm{LNO}_{\mathrm{x}}$. In this case, differences between model-calculated and satellite-retrieved ratios are only apparent when the population threshold approaches 1000 people per $\mathrm{km}^{2}$ (i.e. when large cities such as Los Angeles or Minneapolis are classified as urban and everything else is classified as rural, see map of biases in Fig. 6).

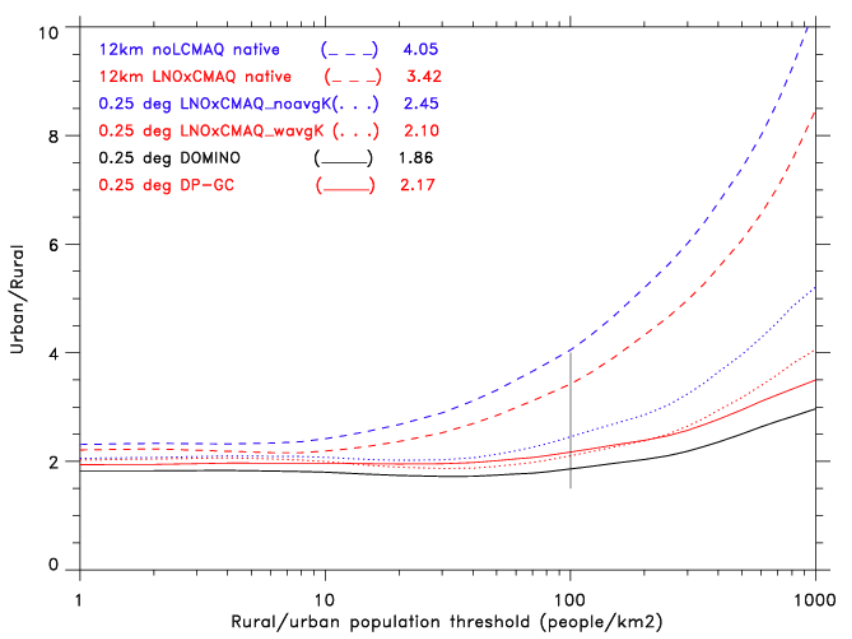

Fig. 7. Ratio between mean urban and rural tropospheric $\mathrm{NO}_{2}$ columns as a function of the population threshold (people $\mathrm{km}^{-2}$ ) used to separate rural and urban grid boxes. The solid black (red) line shows the ratio calculated from the gridded $0.25^{\circ} \times 0.25^{\circ}$ DOMINO (DP-GC) product. The dashed blue (red) line shows the ratio based on 12-km CMAQ output from simulation noL $\left(\mathrm{LNO}_{\mathrm{x}}\right)$. The dotted blue (red) line shows the ratio based on CMAQ simulation $\mathrm{LNO}_{\mathrm{x}}$ output without (with) application of the averaging kernel.

Three factors contribute to the smearing of urban and rural profiles in the DOMINO product. (1) Mean model (and presumably actual) urban to rural $\mathrm{NO}_{2}$ ratios are largest in the surface layer (approximately 6 for a threshold of 100 people $\mathrm{km}^{-2}$ ) and decrease rapidly with height, equaling 4 at $1 \mathrm{~km}, 2$ at $2 \mathrm{~km}$, and 1.5 at $3.5 \mathrm{~km}$. OMI underestimates these ratios because it is relatively insensitive to the lowest $\mathrm{km}$ of the atmosphere. (2) The DOMINO $\mathrm{NO}_{2}$ profile shapes were obtained from a $3^{\circ} \times 2^{\circ}$ simulation with the TM4 model (Boersma et al., 2007). Surface albedos come from a fairly coarse satellite-based climatology. Both of these variables enter into the air mass factor calculation. The use of these relatively coarse profiles and albedos smears urban and rural locations. (3) The footprint of DOMINO pixels is $13 \times 24 \mathrm{~km}$ at nadir but increases as the viewing zenith angle (VZA) increases.

The application of the averaging kernel decreases modelcalculated urban-to-rural ratios because it multiplies lower tropospheric $\mathrm{NO}_{2}$ (where ratios are typically large) by a smaller factor than upper tropospheric $\mathrm{NO}_{2}$ (where ratios are typically small). This efficiency adjustment also means that averaging-kernel processing will induce biases in mean columns at locations where the shape of the model profile is markedly different than the shape of the a priori profile. For example, averaging-kernel processed columns from simulation without lightning-NO emissions are likely to be biased low. The sensitivity to the assumed column shape is also one of the reasons why Lamsal et al. (2010) created the DP-GC 
product for comparison with model output from the GEOSChem model.

To summarize, CMAQ columns in urban areas are biased high with respect to OMI retrievals. However, in general, most of the differences between modeled and satelliteretrieved urban to rural ratios are likely a consequence of the horizontal and vertical smoothing inherent in the OMIretrieved columns. These differences are exacerbated when model profiles differ substantially from priori profiles (see also Huijnen et al., 2010). These results highlight the importance of using averaging kernels when interpreting differences between model and satellite-retrieved columns.

\subsection{Comparison with ozone profiles and columns}

Figure 8a and $\mathrm{b}$ compares the mean summer 2006 tropospheric columns of ozone from OMI and CMAQ. The mean columns at each grid box were calculated using output from days when OMI measurements were available. Retrievals (and model output at same location) with cloud fractions exceeding 0.5 are not included in the averages. Overall, the spatial distribution of the CMAQ columns is similar to the spatial distribution of the OMI columns; however, the CMAQ columns for the simulation with lightning-NO production are 0-5\% higher than the OMI columns over the northern United States and 10-20\% higher than the OMI columns over the southern United States. High-biases of 9-11 DU with respect to the OMI product are common in a region extending from the southern Great Plains to the southeastern United States (Fig. 8c). The bias is not primarily due to an overestimation of lightning-NO production as the lightning-NO contribution (Fig. 8d) shows a southeastern United States peak and equals only 3-5 DU over the southern Great Plains. The amount of vertical information contained in the OMI tropospheric columns is minimal; however, it does suggest that the CMAQ bias with respect to OMI is larger in the upper troposphere than the lower troposphere. Averaged over the region shown in Fig. $8\left(25^{\circ}-50^{\circ} \mathrm{N}, 120^{\circ}-70^{\circ} \mathrm{W}\right)$, CMAQ biases in the two lowest OMI layers (from the surface to approximately $500 \mathrm{hPa}$ ), which contain $46 \%$ of the OMI tropospheric column during this time period equal $4 \%$ while biases in the upper two to four layers equal $20 \%$. By comparison, the one sigma solution errors for OMI at these altitude ranges is $15-20 \%$ (Liu et al., 2010).

Figure 9 compares mean modeled and observed ozone profiles at IONS sites during the summer of 2006. LightningNO production increases model-calculated upper tropospheric $(7-12 \mathrm{~km})$ ozone by $14-19 \mathrm{ppbv}$ over the Houston, Huntsville, and Wallops, Island sites. Compared to the IONS network, the upper tropospheric ozone concentration simulated by CMAQ has very little bias at stations near the western boundary (not shown), but this bias increases for stations in the East. Biases shown here range from 6-8 ppbv at Boulder and Houston to 26-27 ppbv at Huntsville and Wallops Island.
Simulations of upper tropospheric ozone are sensitive to the rate of vertical mixing. If the mixing rate is too vigorous, high ozone concentrations near the stratosphere will be transported downward in excess. This causes the model to overestimate the ozone concentration in the mid and upper troposphere. As air masses move from west to east with the prevailing winds, the excessive vertical mixing increases the bias. This excess ozone can influence the CMAQ calculation of the ozone attributable to lightning NO. To test the impact of this excess ozone, a box model is initialized with observations from INTEX to simulate upper tropospheric chemistry immediately after lightning events (Henderson et al., 2011). Initializing the box model with $20 \%$ additional ozone causes a $10-20 \%$ decrease in ozone production, depending on the level of $\mathrm{NO}_{\mathrm{x}}$. Therefore, the ozone production attributable to lightning NO is likely to be larger than the CMAQ estimate by $10-20 \%$.

\subsection{Impact on surface layer ozone}

For a lightning-NO emission rate of 500 moles per flash, lightning-NO is responsible for $\sim 25 \%$ of the modeled summertime tropospheric $\mathrm{NO}_{2}$ column (Fig. 5). The mean contribution of $\mathrm{LNO}_{\mathrm{x}}$ to surface layer ozone during the same time period is $2.3 \mathrm{ppbv}$ or $\sim 3 \%$ (Fig. 10a). Over the eastern United States, mean contributions are typically $0.5-2.5 \mathrm{ppbv}$ in the north and 2.5-4.5 ppbv in the south. Mean contributions in the southwestern United States exceed $3.5 \mathrm{ppbv}$ at many locations with the largest contributions evident over western Texas, New Mexico, Arizona, and Nevada. The relatively high impact of $\mathrm{LNO}_{\mathrm{x}}$ over the southwestern United States is due to a combination of meteorological and photochemical factors. Flash rates over the southwestern United States are large during July and August due to the North American monsoon. Sunny conditions in this region enhance ozone production and ozone often mixes to the surface due to the high boundary layer heights over the southwest.

Kaynak et al. (2008) used CMAQ to analyze the contribution of lightning-NO production to United States air quality during July-August 2004. They found that lightning-NO increased the domain-wide 8-h ozone maximum by less than 2 ppbv on $71 \%$ of days. Occasionally, at individual grid boxes, they found much larger contributions but these high values were usually on days with good air quality. We obtain similar results with mean contributions of less than $2.5 \mathrm{ppbv}$ at $68 \%$ of grid boxes over the eastern and western United States during the three month period (see Table 1). When we restrict our analysis to grid boxes with poor air quality, we find that the relative importance of lightning-NO emissions to 8-h maximum ozone decreases at eastern United States sites. Over the eastern United States, the contribution of $\mathrm{LNO}_{\mathrm{x}}$ decreases by $1-2 \mathrm{ppbv}$ at most locations (Fig. 10b) and only $20 \%$ of grid boxes show contributions exceeding 2.5 ppbv. Over the western United States, contributions increase at some locations (e.g. eastern California, Nevada, 

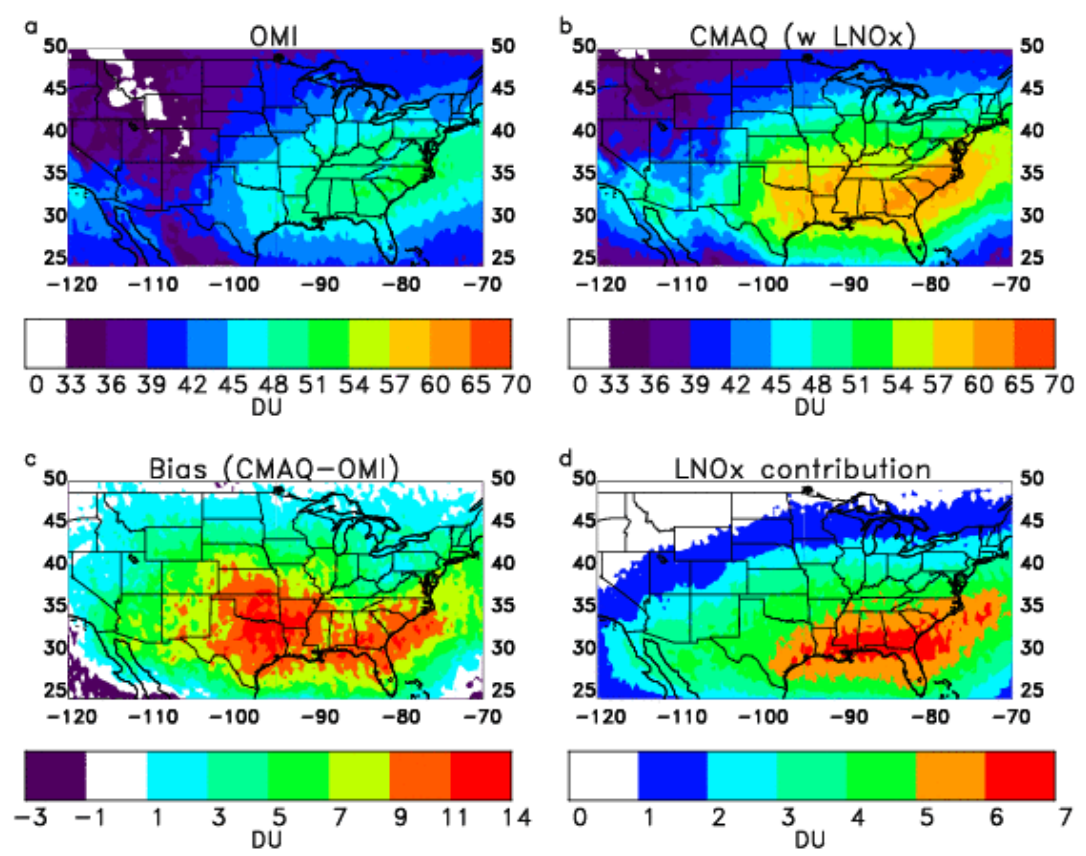

Fig. 8. Mean tropospheric ozone column for 1 June 2006-30 August 2006. Upper left: OMI data, upper right: CMAQ simulation $\mathrm{LNO}_{\mathrm{x}}$ after applying averaging kernel, lower left: bias between averaging kernel processed CMAQ simulation $\mathrm{LNO}_{\mathrm{x}}$ and OMI data, and lower right: lightning-NO contribution to model column (determined without averaging kernel).
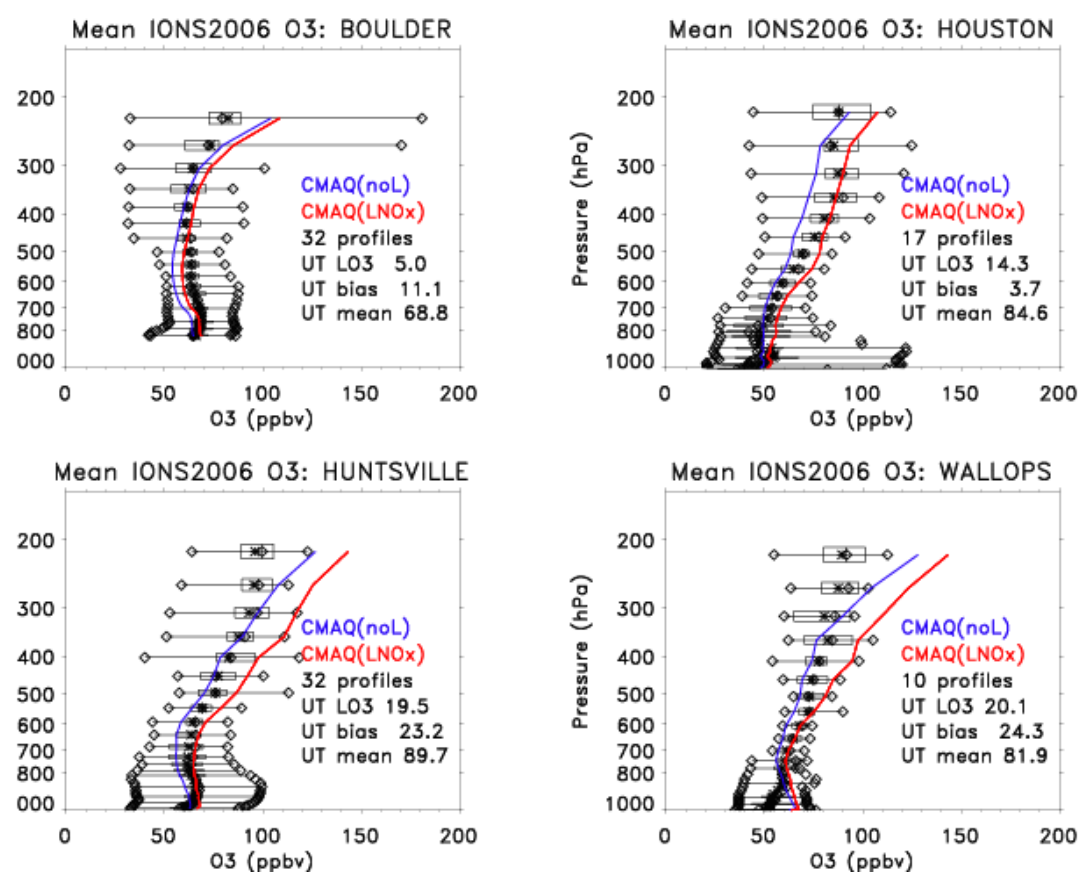

Fig. 9. Mean vertical distribution of ozone at IONS sites during the summer of 2006. Results are shown for Boulder, CO (upper left), Houston, TX (upper right), Huntsville, AL (lower left), and Wallops Island, VA (lower right). CMAQ simulation noL (LNO ${ }_{\mathrm{X}}$ ) is shown in blue (red). For measurements, whiskers show minimum and maximum, while bars show the 25th and 75th percentiles. Median (mean) of measurements is shown with a diamond (asterisk). Numbers in the lower right hand corner show the number of profiles available, the lightning-NO contribution to upper tropospheric (7-12 km) ozone (LO3), the upper tropospheric bias between modeled and measured ozone, and the mean measured upper tropospheric ozone from IONS. 
Table 1. Mean percent of CMAQ grid box-days for which lightning-NO emissions contribute less than $\Delta \mathrm{O}_{3} \mathrm{ppbv}$ to $8 \mathrm{~h}$ maximum ozone values over the western (longitudes west of $100^{\circ} \mathrm{W}$ ) and eastern (longitudes east of $100^{\circ} \mathrm{W}$ ) United States during the $1 \mathrm{June} 2006$ through 31 August 2006 time period. Only populated CMAQ grid boxes within the conterminous United States are used in the calculation. Means are shown for all grid box days and for grid box days with poor air quality. Air quality is considered poor if 8-h maximum ozone from simulation noL on that day exceeds $60 \mathrm{ppbv}$ in that grid box and that value is among the ten highest values at that grid box during the summer. A grid-box day refers to one grid box on one particular day.

\begin{tabular}{|c|c|c|c|c|}
\hline \multicolumn{3}{|c|}{ Western United States } & \multicolumn{2}{|c|}{ Eastern United States } \\
\hline$\Delta \mathrm{O}_{3}$ & $\%$ (All Days) & \% (Poor AQ days) & $\%$ (All Days) & $\%$ (Poor AQ days) \\
\hline$<0.5$ & 37 & 22 & 22 & 18 \\
\hline$<1.5$ & 56 & 47 & 52 & 60 \\
\hline$<2.5$ & 68 & 64 & 68 & 80 \\
\hline$<3.5$ & 76 & 74 & 78 & 88 \\
\hline$<4.5$ & 82 & 81 & 85 & 92 \\
\hline$<5.5$ & 86 & 86 & 90 & 95 \\
\hline$<6.5$ & 90 & 90 & 93 & 97 \\
\hline$<20$ & 100 & 100 & 100 & 100 \\
\hline
\end{tabular}

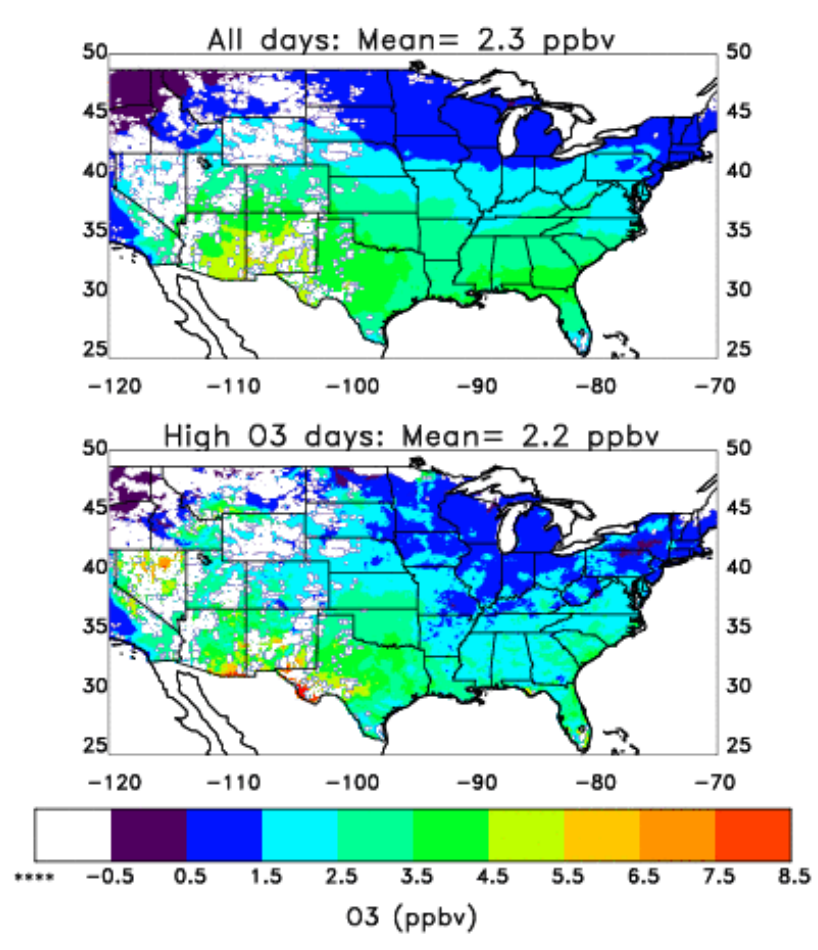

Fig. 10. Mean increase in 8 -h maximum ozone associated with lightning-NO production during the 1 June through 31 August time period. Results averaged over all days (top) and over days when 8-h maximum ozone from simulation noL exceeds $60 \mathrm{ppbv}$ (bottom).

and far western Texas) and decrease at some locations (e.g. Kansas, Oklahoma, and Colorado). Overall, $36 \%$ of western United States grid boxes show contributions exceeding 2.5 ppbv on poor air quality days. Lightning-NO emissions are a substantial contributor $(>6.5 \mathrm{ppbv})$ to $8-\mathrm{h}$ maximum ozone at approximately $10 \%$ of grid points over the western United States and $7 \%$ of grid points over the eastern United States, although the percent of eastern United States grid points with substantial $\mathrm{LNO}_{\mathrm{x}}$ impacts falls to $3 \%$ on poor air quality days.

\subsection{Impact on deposition of nitrogen species}

Table 2 compares the relative contribution of wet and dry processes to the deposition of nitrate and ammonium in the CMAQ model during the June-August 2006 time period. For simulations with lightning-NO emissions, dry and wet deposition processes are of equal importance with total deposition equaling $0.40 \mathrm{~g} \mathrm{~N} \mathrm{ha}^{-1} \mathrm{~h}^{-1}$ for both processes. The relative contribution of nitrate and ammonium to total deposition is sensitive to lightning-NO emissions. For simulations with lightning-NO production, total deposition of nitrate exceeds total deposition of ammonium by $\sim 25 \%$. Differences between the magnitude of nitrate and ammonium deposition are minor for simulations without $\mathrm{LNO}_{\mathrm{x}}$. Overall, wet deposition of nitrate increases by $43 \%$ when lightning-NO emissions are added, while wet deposition of ammonium is virtually unchanged. The $43 \%$ increase in the wet deposition of nitrate corresponds to a $19 \%$ increase in the total deposition of nitrate and a $10 \%$ increase in the total deposition of total nitrogen.

As part of the National Atmospheric Deposition Program (NADP) (NADP, 2006), wet deposition of nitrate and ammonium is routinely measured at approximately $250 \mathrm{Na}$ tional Trends Network (NTN) sites in the United States. Figure 11 compares NADP measurements from the summer of 2006 with CMAQ deposition fields from the same time period. When averaged over the entire domain, model deposition rates agree fortuitously well with measured deposition rates as modeled and measured deposition 
Table 2. Mean dry and wet deposition of nitrate, ammonium, and total nitrogen (N) for June-August 2006 time period from CMAQ simulations without $(\mathrm{noL})$ and with $\left(\mathrm{LNO}_{\mathrm{x}}\right)$ lightning-NO production. Results are obtained by averaging model output over region encompassed by $120^{\circ}-70^{\circ} \mathrm{W}$ and $25^{\circ}-50^{\circ} \mathrm{N}$. Units are $\mathrm{g} \mathrm{N} \mathrm{ha}^{-1} \mathrm{~h}^{-1}$.

\begin{tabular}{lllllll}
\hline & $\begin{array}{l}\text { Drydep } \\
\text { noL }\end{array}$ & $\begin{array}{l}\text { Wetdep } \\
\text { noL }\end{array}$ & $\begin{array}{l}\text { Totdep } \\
\text { noL }\end{array}$ & $\begin{array}{l}\text { Drydep }_{-} \\
\text {LNO }_{x}\end{array}$ & $\begin{array}{l}\text { Wetdep } \\
\text { LNO }_{\mathbf{x}}\end{array}$ & $\begin{array}{l}\text { Totdep } \\
\text { LNO }_{\mathbf{x}}\end{array}$ \\
\hline Nitrate & 0.23 & 0.14 & 0.37 & 0.24 & 0.20 & 0.44 \\
Ammonium & 0.16 & 0.20 & 0.36 & 0.16 & 0.20 & 0.36 \\
Total nitrogen & 0.39 & 0.34 & 0.73 & 0.40 & 0.40 & 0.80 \\
\hline
\end{tabular}

of nitrate equal approximately $0.2 \mathrm{~kg} \mathrm{Nha}^{-1} 30 \mathrm{day}^{-1}$ and modeled and measured deposition of ammonium equal $0.23 \mathrm{~kg} \mathrm{~N} \mathrm{ha}^{-1} 30 \mathrm{day}^{-1}$. Regionally, mean wet deposition of nitrate is overestimated by $8 \%$ in the northeastern United States and by $20-30 \%$ in the southeastern and south central United States. Wet deposition is slightly underestimated over the rest of the United States (i.e. states in Midwest/Great Plains, Rocky Mountain/West). Regional variations in wet deposition of ammonium are larger. Once again, biases are positive in the eastern United States $(\sim 40 \%$ at southeastern states and $\sim 20 \%$ at northeast states) and negative in the western United States (low biases of 20-25\%).

Figure 12 contains scatterplots comparing monthly average modeled and measured wet deposition of nitrate at NADP sites over the western (locations west of $100^{\circ} \mathrm{W}$ ) and eastern (locations east of $100^{\circ} \mathrm{W}$ ) United States. When lightning-NO emissions are not included, mean deposition rates are biased low at western and eastern sites by $33.1 \%$ and $28.9 \%$, respectively. When lightning-NO emissions are included the biases are reduced to near zero $(-2.8 \%$ at western sites and $-0.2 \%$ at eastern sites). The importance of $\mathrm{LNO}_{\mathrm{x}}$ was expected at eastern sites but is somewhat surprising at western sites. Closer examination reveals that less $\mathrm{LNO}_{\mathrm{x}}$ is needed to reduced NMBs at western sites as the mean deposition rates at western sites equal $0.11 \mathrm{~kg} \mathrm{~N} \mathrm{ha}^{-1} 30 \mathrm{day}^{-1}$ while mean deposition rates at eastern sites equal $0.24 \mathrm{~kg} \mathrm{Nha}^{-1} 30 \mathrm{day}^{-1}$. In addition, the bulk of the improvement at western sites occurs east of the Rockies. Wet deposition of nitrate at far western locations (west of $110^{\circ} \mathrm{W}$ ) is underestimated by $41.7 \%$ in simulation noL and $31.5 \%$ in simulation $\mathrm{LNO}_{\mathrm{x}}$ (Table 3). Wet deposition of ammonium is underestimated by $17.2 \%$ at western sites and overestimated by $4.1 \%$ at eastern sites (see Table 3). Lightning-NO emissions have minimal impact on these biases.

Correlations between modeled and measured wet deposition rates at western locations equal 0.70 for nitrate and 0.75 for ammonium (Table 3). Correlations at eastern sites are lower equaling 0.50 and 0.37 , respectively. The lower correlations at eastern sites are likely due to a poorer simulation of week-to-week variations in summertime precipitation at those locations. Table 3 also shows correlations after adjusting for biases in model precipitation. As part of this adjustment, model precipitation totals at NADP sites are replaced by observed precipitation totals at NADP sites. When these adjustments are made, correlations between modeled and measured wet deposition rates increase at both western ( 0.70 to 0.89 for nitrate and 0.75 to 0.86 for ammonium) and eastern sites ( 0.50 to 0.76 for nitrate and 0.37 to 0.66 for ammonium). Unfortunately, adjusting the precipitation at western sites, introduces large negative wet deposition biases of $43 \%(52 \%)$ for nitrate (ammonium). Biases at eastern sites change only slightly after adjusting for biases in precipitation, ranging from $-4.7 \%$ for nitrate to $-1.8 \%$ for ammonium. The large degradation at western sites when precipitation rate are adjusted, indicates that the small biases seen at these locations are due to compensation between overestimated model precipitation rates and underestimated model deposition efficiency.

\subsection{Sensitivity of upper tropospheric $\mathrm{NO}_{\mathrm{x}}$ and $\mathrm{O}_{3}$ to uncertainties in $\mathrm{NO}_{\mathrm{y}}$ chemistry}

We now revisit the CMAQ Summer 2004 36-km simulation driven by MM5 meteorological fields, and compare model output containing $\mathrm{LNO}_{\mathrm{x}}$ with observations from INTEX-A. The INTEX-A field campaign was conducted from 1 July 2004 to 15 August 2004 over North America and the western Atlantic (Singh et al., 2006). Its goals included quantitatively relating the concentrations of trace gases such as $\mathrm{NO}_{\mathrm{x}}$ to their sources. Singh et al. (2007) analyzed reactive nitrogen measurements during INTEX-A. They found unexpectedly large amounts of $\mathrm{NO}_{\mathrm{x}}$ in the upper troposphere and suggested that lightning-NO emissions are a "far greater contributor to $\mathrm{NO}_{\mathrm{x}}$ in the upper troposphere than previously believed". With a few exceptions, modelers have been unable to reproduce these high $\mathrm{NO}_{\mathrm{x}}$ amounts, although increasing the midlatitude NO source to 500 moles per flash helps (Hudman et al., 2007; Pierce et al., 2007; Bousserez et al., 2007; Fang et al., 2010; Allen et al., 2010). This increased lightningNO source is consistent with recent storm-scale field campaigns that indicate that storms with midlatitude characteristics (greater vertical wind shear) and hence longer lightning strokes produce more NO per flash than storms with tropical characteristics (Huntrieser et al., 2008; 2009; Ott et al., 2007, 2010). 

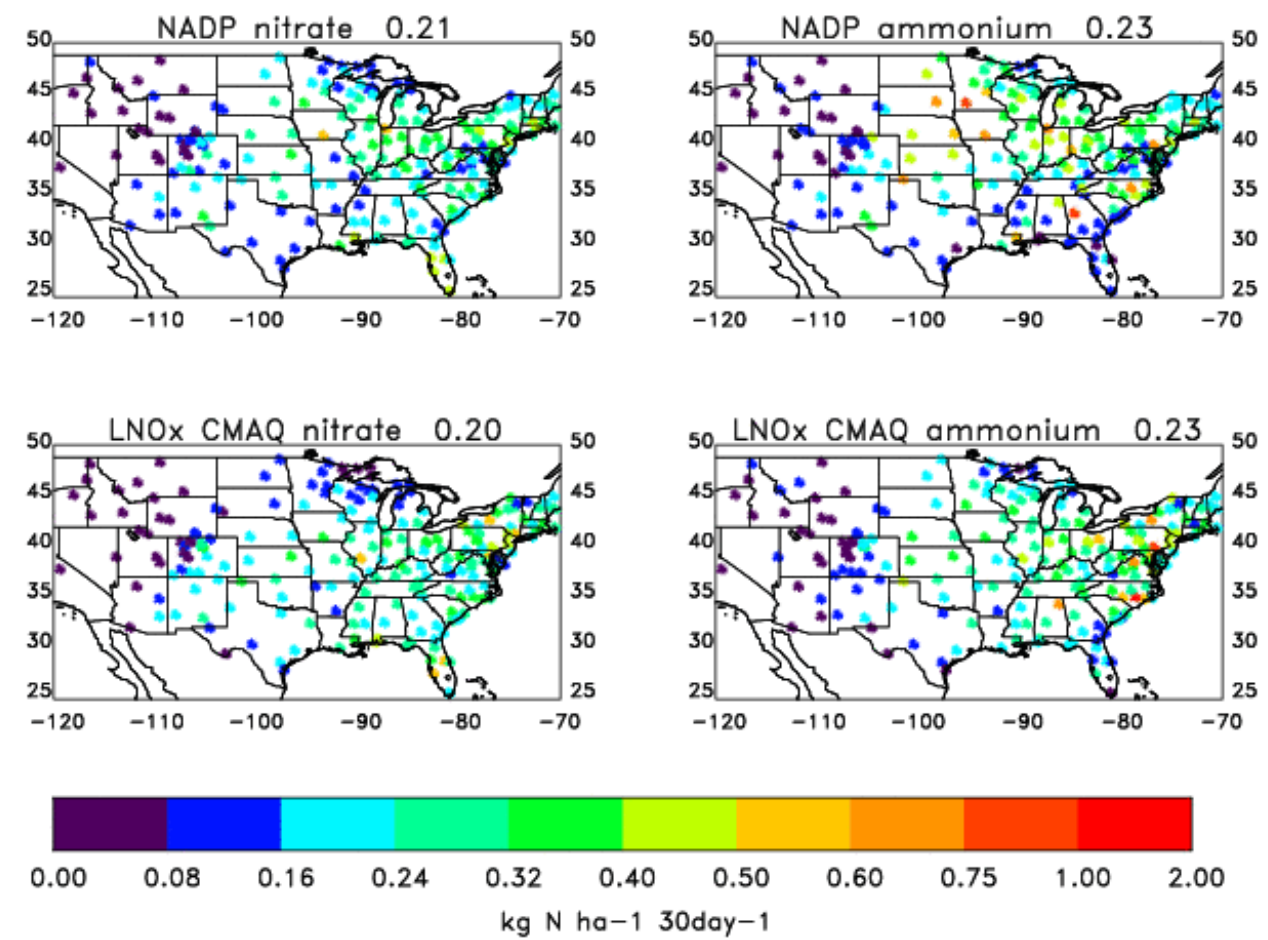

Fig. 11. Summer 2006 wet deposition of nitrogen at NADP/NTP sites. Upper left: nitrate measurements, upper right: ammonium measurements, lower left: nitrate from simulation $\mathrm{LNO}_{\mathrm{X}}$, and lower right: ammonium from simulation $\mathrm{LNO}_{\mathrm{x}}$.
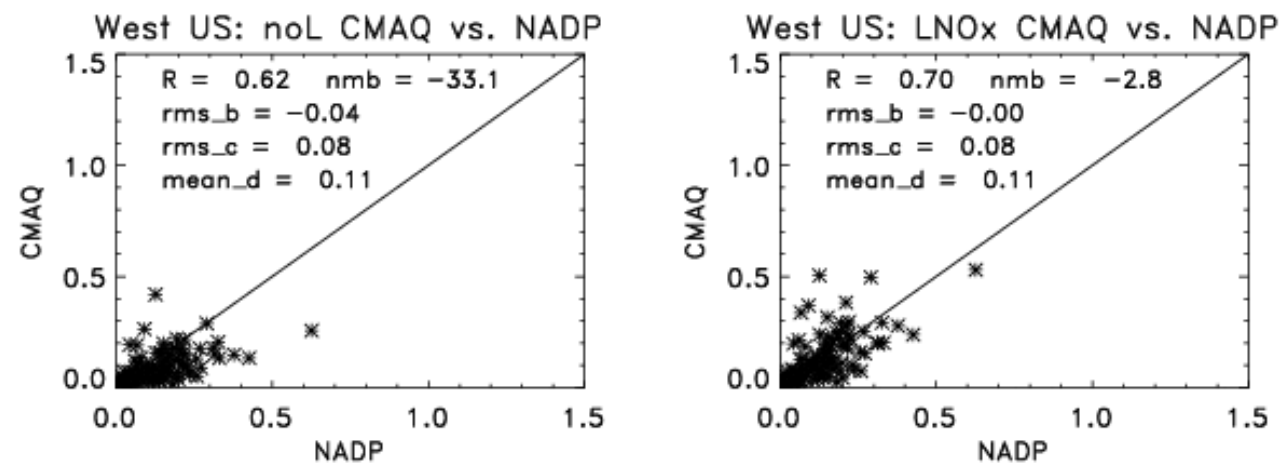

East US: noL CMAQ vs. NADP
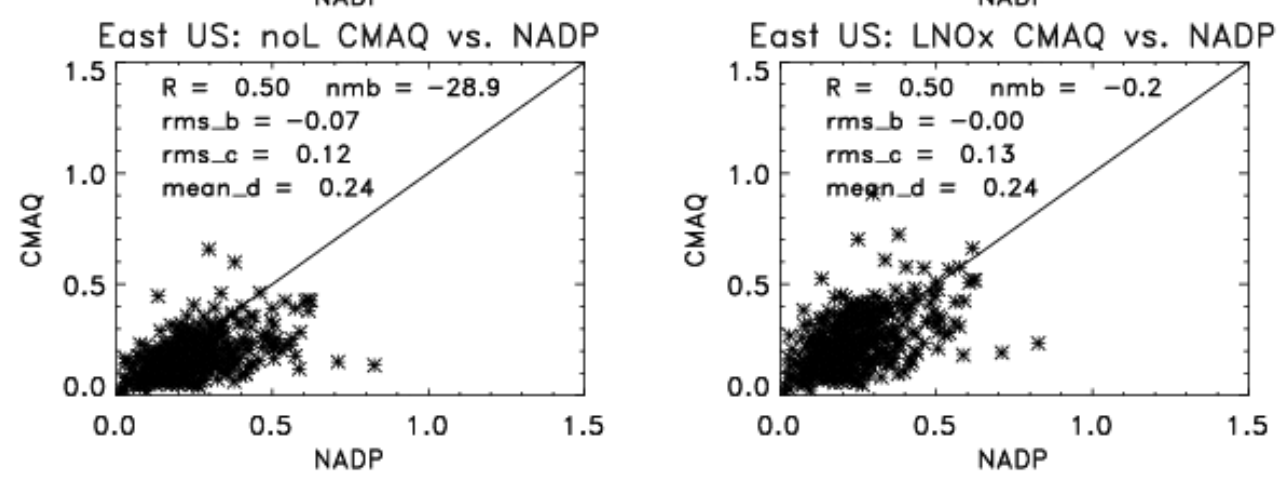

Fig. 12. Scatterplots comparing modeled and measured wet deposition of nitrate at NADP/NTN sites west of $100^{\circ} \mathrm{W}$ (top) and east of $100^{\circ} \mathrm{W}$ (bottom). Model results are shown for simulation noL (left) and $\mathrm{LNO}_{\mathrm{x}}$ (right). Text within each plot shows the correlation $(R)$, the normalized mean bias (nmb), the root mean square bias (rms_b), the centered root mean square bias (rms_c), and the mean of measurements (mean_d). 
Table 3. Thirty-day average wet deposition of nitrate and ammonium from the NADP network, CMAQ simulation noL, and CMAQ simulation $\mathrm{LNO}_{\mathrm{x}}$ are compared for June-August 2006. Results are shown for the western United States (average of 136 months at 65 sites located west of $100^{\circ} \mathrm{W}$ ), eastern United States (average of 397 months at 160 sites east of $100^{\circ} \mathrm{W}$ ), and the far-western United States (nitrate only) (average of 43 months at 25 sites west of $110^{\circ} \mathrm{W}$ ). The "Adj_" rows show the comparison when the CMAQ precipitation rates are replaced by the NADP precipitation rates when calculating the deposition rates. From left to right the columns show the region of interest, the data sets compared, the correlation coefficient, the mean of the NADP measurements $\left(\mathrm{kg} \mathrm{of} \mathrm{N} \mathrm{ha}^{-1} 30\right.$ days $^{-1}$ ), the normalized mean bias, the bias, and the root mean square error after subtracting the bias.

\begin{tabular}{|c|c|c|c|c|c|c|}
\hline & & $R$ & Mean_d & NMB & RMS_b & RMS_c \\
\hline \multirow{4}{*}{$\begin{array}{l}\text { West US } \\
\text { nitrate }\end{array}$} & noL/NADP & 0.62 & \multirow{4}{*}{0.11} & -33.1 & -0.04 & 0.08 \\
\hline & $\mathrm{LNO}_{\mathrm{X}} / \mathrm{NADP}$ & 0.70 & & -02.8 & -0.00 & 0.08 \\
\hline & Adj_noL/NADP & 0.87 & & -62.0 & -0.07 & 0.07 \\
\hline & Adj_LNO ${ }_{x} / \mathrm{NADP}$ & 0.89 & & -43.5 & -0.05 & 0.05 \\
\hline \multirow{4}{*}{$\begin{array}{l}\text { WestUS } \\
\text { ammonium }\end{array}$} & noL/NADP & 0.74 & \multirow{4}{*}{0.13} & -17.9 & -0.02 & 0.10 \\
\hline & $\mathrm{LNO}_{\mathrm{X}} / \mathrm{NADP}$ & 0.75 & & -17.2 & -0.02 & 0.10 \\
\hline & Adj_noL/NADP & 0.86 & & -52.3 & -0.07 & 0.09 \\
\hline & $\operatorname{Adj} L \mathrm{LNO}_{\mathrm{x}} / \mathrm{NADP}$ & 0.86 & & -52.0 & -0.07 & 0.09 \\
\hline \multirow{4}{*}{$\begin{array}{l}\text { East US } \\
\text { nitrate }\end{array}$} & noL/NADP & 0.50 & \multirow{4}{*}{0.24} & -28.9 & -0.07 & 0.12 \\
\hline & $\mathrm{LNO}_{\mathrm{X}} / \mathrm{NADP}$ & 0.50 & & -00.2 & -0.00 & 0.13 \\
\hline & Adj_noL/NADP & 0.70 & & -30.7 & -0.07 & 0.10 \\
\hline & $\operatorname{Adj} \mathrm{LNO}_{\mathrm{x}} / \mathrm{NADP}$ & 0.76 & & -04.7 & -0.01 & 0.10 \\
\hline \multirow{4}{*}{$\begin{array}{l}\text { East US } \\
\text { ammonium }\end{array}$} & noL/NADP & 0.37 & \multirow{4}{*}{0.27} & +3.7 & +0.01 & 0.21 \\
\hline & $\mathrm{LNO}_{\mathrm{X}} / \mathrm{NADP}$ & 0.37 & & +4.1 & +0.01 & 0.21 \\
\hline & Adj_noL/NADP & 0.65 & & -2.2 & -0.01 & 0.15 \\
\hline & $\operatorname{Adj} \_L_{N} O_{x} / N A D P$ & 0.66 & & -1.8 & -0.00 & 0.15 \\
\hline \multirow{4}{*}{$\begin{array}{l}\text { Far West US } \\
\text { nitrate }\end{array}$} & noL/NADP & 0.47 & & -41.7 & -0.02 & 0.04 \\
\hline & $\mathrm{LNO}_{\mathrm{x}} / \mathrm{NADP}$ & 0.59 & & -31.5 & -0.02 & 0.04 \\
\hline & Adj_noL/NADP & 0.70 & & -56.8 & -0.03 & 0.04 \\
\hline & Adj_LNO ${ }_{x} / \mathrm{NADP}$ & 0.83 & & -48.0 & -0.02 & 0.03 \\
\hline
\end{tabular}

The primary aircraft used during INTEX-A was NASA's DC-8, and one-minute merge data sets are available for all species measured aboard the DC-8. We compared CMAQ output with these measurements after removing one-minute periods when contributions from fresh pollution, biomass burning, or stratosphere-troposphere exchange were greatly enhanced (see Allen et al., 2010, for methodology) Samples with greatly enhanced fresh pollution or biomass burning were removed as they are likely unrepresentative of the 36-km CMAQ grid box. Samples with a greatly enhanced stratospheric contribution were removed because this study focuses on the upper troposphere. Unlike Allen et al. (2010), we did not have tropopause pressure information from the meteorological model and were unable to use that parameter as an additional stratospheric filter.

Figure 13 shows the contribution of $\mathrm{LNO}_{\mathrm{x}}$ to $\mathrm{NO}_{2}$ during DC-8 flight 4 of INTEX-A. The DC- 8 measured increasingly high $\mathrm{NO}_{\mathrm{x}}$ amounts in the upper troposphere during the latter portion of the flight as the DC- 8 moved across Illinois, Michigan, and Indiana. Ozone amounts also increased over this region (see Fig. 14). CMAQ simulation $\mathrm{LNO}_{\mathrm{x}}$ also showed high amounts of $\mathrm{NO}_{2}$ and relatively high amounts of ozone over much of this region. $\mathrm{NO}_{2}$ and ozone amounts in the noL simulation did not increase over this region. In order to look at the impact of $\mathrm{LNO}_{\mathrm{x}}$ on upper tropospheric composition during this flight, mean $\mathrm{NO}_{\mathrm{x}}$ and ozone concentrations in the upper troposphere (pressures less than $500 \mathrm{hPa}$ ) were calculated for the time period before 14:30EDT (when the impact of lightning-NO emissions was small) and the time period after 14:30 EDT (when the impact of lightning-NO emissions was large). The early period had 52 one-minute observations while the latter period had 63 one-minute observations (see Table 4). Measured upper tropospheric $\mathrm{NO}_{2}$ equaled $39 \mathrm{pptv}$ during the early period and $136 \mathrm{pptv}$ during the latter period. Modeled $\mathrm{NO}_{2}$ from simulation noL equaled 6(10) pptv for the early (latter) period, while modeled $\mathrm{NO}_{\mathrm{x}}$ from simulation $\mathrm{LNO}_{\mathrm{x}}$ equaled 6 (104) pptv for the same periods. Measured ozone equaled $66.7 \mathrm{ppbv}$ during the early period and $79.8 \mathrm{ppbv}$ during the latter period. Modeled ozone from simulation noL equaled 60.2 (57.3) ppbv for the early (latter) period, while modeled ozone from simulation $\mathrm{LNO}_{\mathrm{x}}$ equaled 60.2 (67.4) ppbv for the same periods. Overall, the data shows an increase of $13.1 \mathrm{ppbv}$ in upper tropospheric ozone between the early and latter periods. Model 

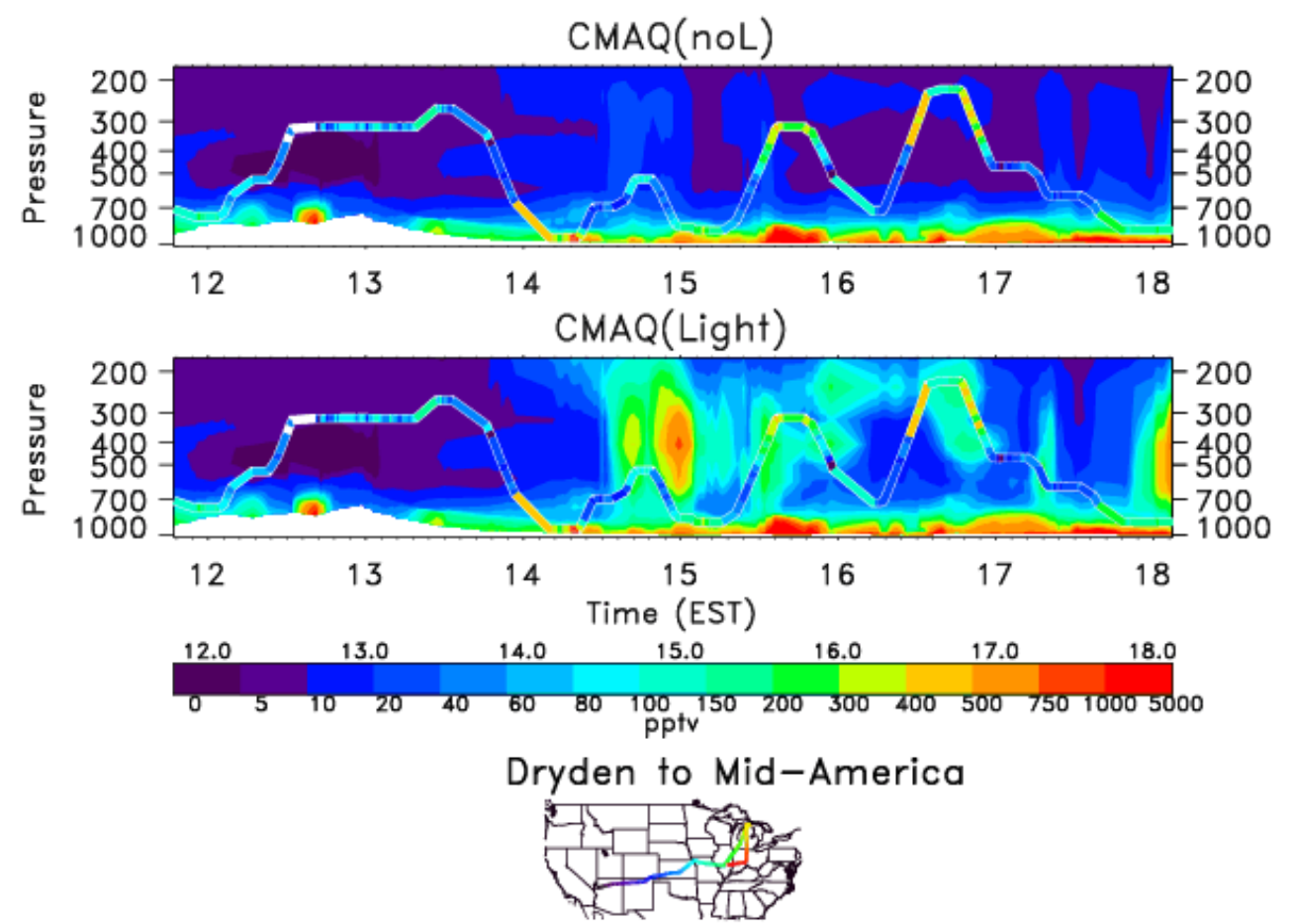

Fig. 13. Curtain plot comparing model $\mathrm{NO}_{2}$ as a function of time (EST) and pressure (hPa) with measurements from DC-8 Flight 4 on 6 July 2004. Top (bottom) panel shows results from simulation noL $\left(\mathrm{LNO}_{\mathrm{x}}\right)$. Measured values are shown with a ribbon. Model values are shown in the background. The location and time of INTEX-A samples are shown on the United States map. The color bar shows the time of one-minute average samples and the scale for the $\mathrm{NO}_{\mathrm{x}}$ measurements.
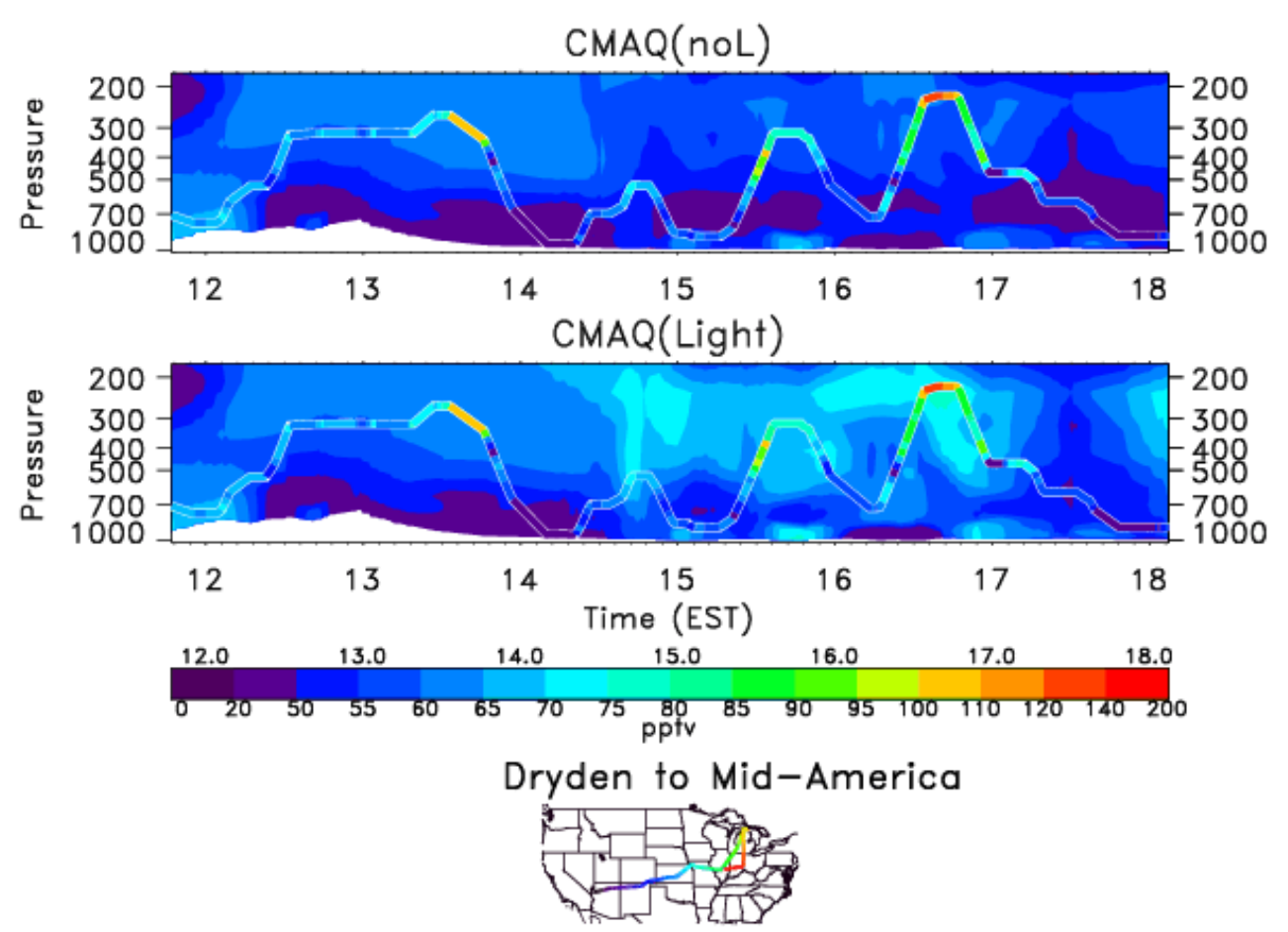

Fig. 14. Same as Fig. 13 but for ozone. 
Table 4. Mean upper tropospheric (Pressure $<500 \mathrm{hPa}$ ) mixing ratios of $\mathrm{NO}_{2}$ and ozone before and after 02:30 p.m. EST for INTEX-A DC-8 Flight 4. Measurements are compared with CMAQ simulations noL, $\mathrm{LNO}_{\mathrm{x}}$, adjChemLNO $\mathrm{x}_{\mathrm{x}}$, and airLNO . Adj_MPN column gives an estimate of $\mathrm{NO}_{2}$ amounts assuming MPN and $\mathrm{HO}_{2} \mathrm{NO}_{2}$ interferences have the temperature dependence shown in Fig. 2 of Browne et al. (2011). Units are pptv for $\mathrm{NO}_{2}$ and ppbv for ozone.

\begin{tabular}{lrrrrrr}
\hline & $\begin{array}{r}\text { INTEX-A } \\
\text { Measurements }\end{array}$ & $\begin{array}{r}\text { INTEX-A } \\
\text { Measurement } \\
\text { Adj_MPN }\end{array}$ & noL & LNO $_{\mathrm{x}}$ & $\begin{array}{r}\text { adjChem } \\
\text { LNO }_{\mathrm{x}}\end{array}$ & airLNO \\
\hline $\mathrm{NO}_{2}$ (before) & 57 & 39 & 6 & 6 & 9 & 11 \\
$\mathrm{NO}_{2}$ (after) & 192 & 136 & 10 & 104 & 151 & 109 \\
$\mathrm{O}_{3}$ (before) & 66.7 & N/A & 60.2 & 60.2 & 62.4 & 60.7 \\
$\mathrm{O}_{3}$ (after) & 79.8 & N/A & 57.3 & 67.4 & 69.9 & 68.0 \\
\hline
\end{tabular}

ozone increases by $7.2 \mathrm{ppbv}$ when lightning-NO emissions are included but decreases by $2.9 \mathrm{ppbv}$ in simulation noL that did not include lightning-NO emissions. Observed $\mathrm{NO}_{2}$ increases by a factor of three between the early and latter periods, while model $\mathrm{NO}_{2}$ in simulation $\mathrm{LNO}_{\mathrm{x}}$ increases by nearly a factor of 20 between the same periods. Clearly, upper tropospheric model $\mathrm{NO}_{2}$ is biased low with respect to the measurements, especially during periods when the impact of lightning-NO emissions is small. Table 4 also shows that the impact of aircraft $\mathrm{NO}$ emissions on upper tropospheric $\mathrm{NO}_{2}$ and ozone along this particular flight track. Overall, aircraft emissions increase model $\mathrm{NO}_{2}$ by 5 pptv. This increase is small; however, it can lead to large percentage changes in upper tropospheric $\mathrm{NO}_{2}$ during periods when the impact of lightning-NO emissions is small. Upper tropospheric ozone increased by approximately $1 \%$ when aircraft emissions were included.

The low-bias in upper tropospheric $\mathrm{NO}_{2}$ is not restricted to Flight 4. Figure 15 compares mean modeled and measured $\mathrm{NO}_{2}$ during the entire INTEX-A campaign. Model $\mathrm{NO}_{2}$ from simulation $\mathrm{LNO}_{\mathrm{x}}$ is approximately a factor of two less than observed $\mathrm{NO}_{2}$ at $9 \mathrm{~km}$ and a factor of four less than observed $\mathrm{NO}_{2}$ at $12 \mathrm{~km}$. Several factors may contribute to the sizeable bias between modeled and measured $\mathrm{NO}_{2}$ including biases in model convection, measurements, and model chemistry. For example, if model clouds do not extend high enough into the upper troposphere, the lofting of boundary layer ozone precursors and the vertical extent of NO with a lightning source will be underestimated. As another example, the upper tropospheric lifetime of $\mathrm{NO}_{\mathrm{x}}$ is believed to be too short in atmospheric models (Henderson et al., 2011). In addition, INTEX-A measurements of $\mathrm{NO}_{2}$ are likely to have a high-bias in the upper troposphere due to interference from methyl peroxy nitrate (MPN) and to a lesser degree peroxy nitric acid $\left(\mathrm{HO}_{2} \mathrm{NO}_{2}\right)$ (Browne et al., 2011). Post-mission analysis indicated that $48-77 \%$ of MPN and 3-6\% of $\mathrm{HO}_{2} \mathrm{NO}_{2}$ dissociate in the inlet and are recorded as $\mathrm{NO}_{2}$. Calculations with a photostationary state model indicate that MPN and $\mathrm{HO}_{2} \mathrm{NO}_{2}$ concentrations are small with respect to $\mathrm{NO}_{2}$ in the lower troposphere where

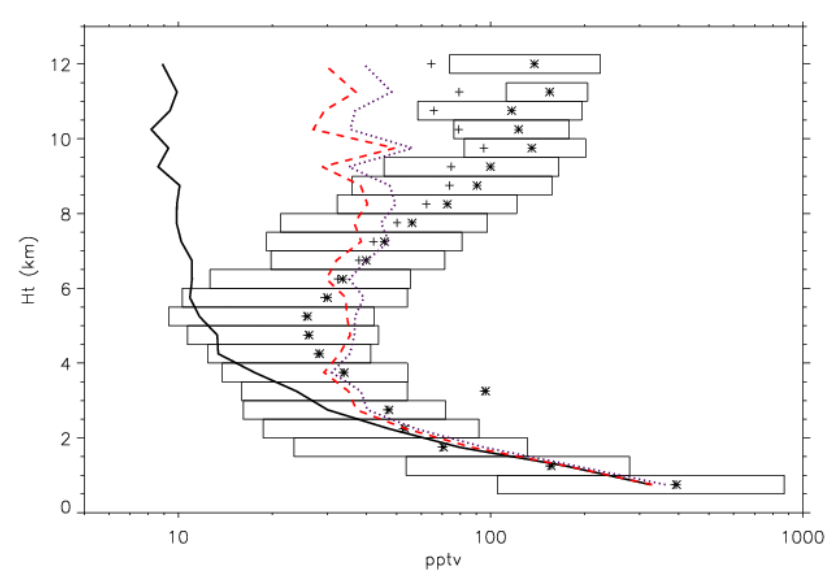

Fig. 15. Vertical distribution of $\mathrm{NO}_{2}$ during INTEX-A. Means of medians from 16 DC-8 flights are shown by asterisks ("+" symbols) before (after) adjustment for MPN and $\mathrm{HO}_{2} \mathrm{NO}_{2}$ interference. Box edges show mean 10th and 90th percentiles for the 16 flights. Model means of medians from simulations noL (solid black line), $\mathrm{LNO}_{\mathrm{x}}$ (dashed red line), and $\mathrm{LNO}_{\mathrm{x}}$ adjChem (purple dotted line) are also shown.

temperatures are mild. However, MPN and to a lesser degree $\mathrm{HO}_{2} \mathrm{NO}_{2}$ concentrations increase rapidly as temperatures decrease and may exceed $\mathrm{NO}_{2}$ concentrations at temperatures below $240 \mathrm{~K}$. Browne et al. (2011) estimated the interference as a function of temperature using a photostationary state model constrained by measurements from the NASA Arctic Research of the Composition of the Troposphere from Aircraft and Satellites (ARCTAS) field campaign (see their Fig. 2). If this same relationship is assumed for INTEX-A, $\mathrm{NO}_{2}$ measurements in the upper troposphere during DC-8 Flight 4 are biased high by approximately $30 \%$ (see Table 4).

When averaged over all INTEX-A flight days, biases in mid- and upper-troposphere $\mathrm{HO}_{\mathrm{x}}$ (after multiplying measured $\mathrm{HO}_{\mathrm{x}}$ by 1.64 to account by interferences discussed in Ren et al., 2008) are minor for simulation $\mathrm{LNO}_{\mathrm{x}}(1.5 \%$ too high at $7-9 \mathrm{~km}$ and $4.7 \%$ too high at $9-12 \mathrm{~km}$ ) [not shown]. Biases for $\mathrm{HO}_{2}$ are also small in these altitude ranges $(2 \%$ 
Table 5. Mean 7-9 km and 9-12 km mixing ratios of $\mathrm{NO}_{2}$ and ozone from 16 DC-8 flights during INTEX-A. Measurements are compared with CMAQ simulations noL, $\mathrm{LNO}_{\mathrm{x}}$, adjChemLNO $\mathrm{x}_{\mathrm{x}}$, and airLNO

\begin{tabular}{lrrrrrr}
\hline & $\begin{array}{r}\text { INTEX-A } \\
\text { Measurements }\end{array}$ & $\begin{array}{r}\text { INTEX-A } \\
\text { Measurement } \\
\text { Adj_MPN }\end{array}$ & noL & LNO $_{\mathrm{x}}$ & $\begin{array}{r}\text { adjChem } \\
\mathrm{LNO}_{\mathrm{x}}\end{array}$ & airLNO \\
\hline $\mathrm{NO}_{2}(7-9 \mathrm{~km})$ & 63 & 54 & 10 & 37 & 45 & 39 \\
$\mathrm{NO}_{2}(9-12 \mathrm{~km})$ & 123 & 73 & 9 & 32 & 40 & 34 \\
$\mathrm{O}_{3}(7-9 \mathrm{~km})$ & 76.5 & N/A & 56.9 & 61.8 & 63.7 & 62.4 \\
$\mathrm{O}_{3}(9-12 \mathrm{~km})$ & 81.7 & N/A & 57.7 & 63.3 & 65.4 & 64.0 \\
\hline
\end{tabular}

high at $7-9 \mathrm{~km}$ and $7 \%$ high at $9-12 \mathrm{~km}$ ). Model $\mathrm{OH}$ has a low-bias of $21 \%$ for $7-9 \mathrm{~km}$ and $47 \%$ for $9-12 \mathrm{~km}$. Thus the low-bias in $\mathrm{NO}_{\mathrm{x}}$ is not believed to be caused by excessive $\mathrm{OH}$.

The sensitivity of upper tropospheric $\mathrm{NO}_{2}$ to uncertainties in $\mathrm{NO}_{\mathrm{y}}$ chemistry is shown for DC-8 Flight 4 in Table 4 and for the entire campaign in Fig. 15a and b and Table 5. Model 7-9 km (9-12 km) $\mathrm{NO}_{2}$ increases from 37 to 45 (32 to 40 ) pptv when the chemical mechanism is adjusted. This chemically-induced increase reduces the model low-bias from 41 to $29 \%$ for $7-9 \mathrm{~km}$ and from 74 to $67 \%$ for $9-12 \mathrm{~km}$. Of course the percentage reduction is larger if the measurements are corrected for possible interferences by MPN and $\mathrm{HO}_{2} \mathrm{NO}_{2}$. In this instance, model $\mathrm{NO}_{2}$ biases are reduced from 32 to $17 \%$ for $7-9 \mathrm{~km}$ and from 57 to $46 \%$ for $9-12 \mathrm{~km}$.

\section{Summary and conclusion}

A lightning-NO parameterization scheme has been implemented in the CMAQ model and used to evaluate the impact of lightning-NO emissions on tropospheric photochemistry over the eastern two-thirds of the United States during the summers of 2004 and 2006. The scheme assumes flash rates are proportional to the model-calculated convective precipitation rate but then adjusts the flash rates locally so that flash rates when averaged over a month approximate NLDN-based estimates of the total flash rate.

For a relatively large lightning-NO source of 500 moles per flash, lightning-NO emissions account for $\sim 25 \%$ of the summer $2006 \mathrm{CMAQ}$ tropospheric $\mathrm{NO}_{2}$ column over the eastern United States and adjacent western Atlantic It also adds $15-20 \mathrm{ppbv}$ to southeastern United States upper tropospheric ozone amounts. The mean model-calculated tropospheric $\mathrm{NO}_{2}$ column with this lightning-NO source agrees with satellite-retrieved columns to within -5 to $+13 \%$. CMAQ exhibited some skill in capturing day-today variations in satellite-retrieved columns $(r=0.47$ with respect to DOMINO product and 0.79 with respect to DPGC product). Model tropospheric $\mathrm{NO}_{2}$ columns over urban regions exceed satellite-retrieved columns. Biases between model-calculated and satellite-retrieved columns at other locations are relatively small after accounting for lightning-NO emissions and the vertical and horizontal smoothing inherent in $\mathrm{OMI} \mathrm{NO}_{2}$ averaging kernels.

When averaged over the summer of 2006 (a summer with a larger than normal source of ozone from lightning-NO), lightning-NO emissions contribute an average of $2.3 \mathrm{ppbv}$ to 8-h maximum surface layer ozone concentrations over the conterminous United States; however, this estimate is likely biased high as the model has excessive vertical mixing. Regional variations are large with contributions of 3.5-5.5, 2.54.5 , and $0.5-2.5 \mathrm{ppbv}$ being typical over the southwestern, southeastern, and northeastern United States. Over the eastern United States, the contribution of lightning-NO emissions to surface ozone is typically $1-2$ ppbv smaller on poor air quality days than on good air quality days. Over the western United States, the contribution of $\mathrm{LNO}_{\mathrm{x}}$ to surface ozone is uncorrelated with air quality.

Within CMAQ, dry and wet deposition processes contribute equally to nitrogen deposition over the United States. As expected, lightning-NO production has no impact on deposition of ammonium and only a minor impact on dry deposition of nitrate; however, lightning-NO production increases the mean wet deposition of nitrate by $43 \%$. Wet deposition rates of nitrate are reasonably well simulated by CMAQ with regional biases being less than $30 \%$ throughout the United States. Biases are largest over the southeastern United States and appear to be due to an overestimation of model precipitation. However, the good agreement at western sites is mostly fortuitous as the low biases at these locations result from compensation between overestimated model precipitation rates and underestimated model deposition efficiencies. Wet deposition rates of ammonium are not as well simulated with positive biases of $20-40 \%$ over the eastern United States and negative biases of 20-25\% over the western United States.

CMAQ like most chemistry and transport models underestimated upper tropospheric $\mathrm{NO}_{2}$ and $\mathrm{NO}_{\mathrm{x}}$ during the INTEXA field campaign. Several factors including incomplete model chemistry and interferences in measured $\mathrm{NO}_{2}$ contributed to the bias. When averaged over the entire campaign, 
upper tropospheric $\mathrm{NO}_{2}$ biases for the standard simulation were $42 \%$ for $7-9 \mathrm{~km}$ and $74 \%$ for $9-12 \mathrm{~km}$. These biases were reduced to $29 \%$ and $68 \%$, respectively for the simulation with revised chemistry. If measurements are adjusted to account for interferences, the inclusion of updated chemistry reduces biases from 32 to $17 \%$ for $7-9 \mathrm{~km}$ and 57 to $46 \%$ for $9-12 \mathrm{~km}$. The chemistry sensitivity simulation represents an upper bound impact. The organic nitrate yield (designed for the upper troposphere) most likely also increases $\mathrm{NO}_{\mathrm{x}}$ export from the surface where this change has not been evaluated. While these changes lead to better agreement, a considerable $\mathrm{NO}_{2}$ low-bias remains in the uppermost troposphere.

Acknowledgements. This work was supported by a ROSES07 Decision Support through Earth Science Research Results project funded by the NASA Applied Sciences Air Quality Program. We thank Tom Pierce for his guidance on this project and his comments on the manuscript. We also thank Ronald Cohen and Eleanor Browne for helpful conversations regarding $\mathrm{NO}_{\mathrm{y}}$ measurement uncertainties.

Disclaimer: Although this paper has been reviewed by the EPA and approved for publication, it does not necessarily reflect EPA policies or views.

Edited by: B. Vogel

\section{References}

Allen, D., Pickering, K., Duncan, B., and Damon, M.: Impact of lightning NO emissions on North American photochemistry as determined using the Global Modeling Initiative (GMI) model, J. Geophys. Res., 115, D22301, doi:10.1029/2010JD014062, 2010.

Baughcum, S. L., Tritz, T. G., Henderson, S. C., and Pickett, D. C.: Scheduled civil aircraft emission inventories for 1992: Database development and analysis, NASA CR-4700, NASA, Washington DC, 1996.

Beirle, S., Huntrieser, H., and Wagner, T.: Direct satellite observation of lightning-produced $\mathrm{NO}_{\mathrm{x}}$, Atmos. Chem. Phys., 10, 10965-10986, doi:10.5194/acp-10-10965-2010, 2010.

Bey, I., Jacob, D. J., Yantosca, R. M., Logan, J. A., Field, B. D., Fiore, A. M., Li, Q., Liu, H. Y., Mickley, L. J., and Schultz, M. G.: Global modeling of tropospheric chemistry with assimilated meteorology: model description and evaluation, J. Geophys. Res., 106, 23073-23095, 2001.

Biagi, C. J., Cummins, K. L., Kehoe, K. E., and Krider, E. P.: National Lightning Detection Network (NLDN) performance in southern Arizona, Texas, and Oklahoma in 2003-2004, J. Geophys. Res., 112, D05208, doi:1029/2006DJ007341, 2007.

Boccippio, D., Cummins, K., Christian, H., and Goodman, S.: Combined Satellite- and Surface-Based Estimation of the Intracloud-Cloud-to-Ground Lightning Ratio over the Continental United States, Mon. Weather Rev., 129, 108-122, 2001.

Boccippio, D. J., Koshak, W. J., and Blakeslee, R. J.: Performance assessment of the Optical Transient Detector and Lightning Imaging Sensor, I: Predicted diurnal variability, J. Atmos. Ocean. Tech., 19, 1318-1332, 2002.

Boersma, K. F., Eskes, H. J., Veefkind, J. P., Brinksma, E. J., van der A, R. J., Sneep, M., van den Oord, G. H. J., Levelt, P. F.,
Stammes, P., Gleason, J. F., and Bucsela, E. J.: Near-real time retrieval of tropospheric $\mathrm{NO}_{2}$ from OMI, Atmos. Chem. Phys., 7, 2103-2118, doi:10.5194/acp-7-2103-2007, 2007.

Boersma, K. F., Dirksen, R. J., Veefkind, J. P., Eskes, H. J., and van der A, R. J.: Dutch OMI $\mathrm{NO}_{2}$ (DOMINO) data product:, HE5 data file user manual, available at: http://www.temis.nl/ docs/OMI_NO2_HE5_1.0.2.pdf, 2009.

Boersma, K. F., Eskes, H. J., Dirksen, R. J., van der A, R. J., Veefkind, J. P., Stammes, P., Huijnen, V., Kleipool, Q. L., Sneep, M., Claas, J., Leitão, J., Richter, A., Zhou, Y., and Brunner, D.: An improved tropospheric $\mathrm{NO}_{2}$ column retrieval algorithm for the Ozone Monitoring Instrument, Atmos. Meas. Tech., 4, 19051928, doi:10.5194/amt-4-1905-2011, 2011.

Bousserez, N., Atti, J. L., Peuch, V. H., Michou, M., Pfister, G., Edwards, D., Emmons, L., Mari, C., Barret, B., Arnold, S. R., Heckel, A., Richter, A., Schlager, H., Lewis, A., Avery, M., Sachse, G., Browell, E. V., and Hair, J. W.: Evaluation of the MOCAGE chemistry transport model during the ICARTT/ITOP experiment, J. Geophys. Res., 112, D10S42, doi:10.1029/2006JD007595, 2007.

Bovensmann, H., Burrows, J. P., Buchwitz, M., Frerick, J., Noël, S., Rozanov, V. V., Chance, K. V., and Goede, A. P. H.: SCIAMACHY: Mission Objectives and Measurement Modes, J. Atmos. Sci., 56, 127-150, 1999.

Browne, E. C., Perring, A. E., Wooldridge, P. J., Apel, E., Hall, S. R., Huey, L. G., Mao, J., Spencer, K. M., Clair, J. M. St., Weinheimer, A. J., Wisthaler, A., and Cohen, R. C.: Global and regional effects of the photochemistry of $\mathrm{CH}_{3} \mathrm{O}_{2} \mathrm{NO}_{2}$ : evidence from ARCTAS, Atmos. Chem. Phys., 11, 4209-4219, doi:10.5194/acp-11-4209-2011, 2011.

Bucsela, E. J., Perring, A. E., Cohen, R. C., Boersma, K. F., Celarier, E. A., Gleason, J. F., Wenig, M. O., Bertram, T. H., Wooldridge, P. J., Dirksen, R., and Veefkind, J. P.: Comparison of tropospheric $\mathrm{NO}_{2}$ from in situ aircraft measurements with near-real-time and standard product data from OMI, J. Geophys. Res., 113, D16S31, doi:10.1029/2007JD008838, 2008.

Byun, D. W. and Schere, K. L.: Review of the governing equations, computational algorithms, and other components of the Models3 Community Multiscale Air Quality (CMAQ) modeling system, Appl. Mech. Rev., 59, 51-77, 2006.

Castellanos, P., Marufu, L. T., Doddridge, B. G., Taubman, B. F., Schwab, J. J., Hains, J. C., Ehrman, S. H., and Dickerson, R. R.: Ozone, oxides of nitrogen, and carbon monoxide during pollution events over the eastern United States: An evaluation of emissions and vertical mixing, J. Geophys. Res., 116, D16307, doi:10.1029/2010JD014540, 2011.

Celarier, E. and Retscher, C.: OMINO2e data product readme file, available at: http://toms.gsfc.nasa.gov/omi/no2/OMNO2e_ DP_Readme.pdf, 2009.

Choi, Y., Wang, Y., Yang, Q., Cunnold, D., Zeng, T., Shim, C., Luo, M., Eldering, A., Bucsela, E., and Gleason, J.: Spring to summer northward migration of high ozone over the western North Atlantic, Geophys. Res. Lett., 35, L04818, doi:10.1029/2007GL032276, 2008.

Cooper, O. R., Stohl, A., Trainer, M., Thompson, A. M., Witte, J. C., Oltmans, S. J., Morris, G., Pickering, K. E., Crawford, J. H., Chen, G., Cohen, R. C., Bertram, T. H., Wooldridge, P., Perring, A., Brune, W. H., Merrill, J., Moody, J. L., Tarasick, D., N'ed'elec, P., Forbes, G., Newchurch, M. J., Schmidlin, F. J., 
Johnson, B. J., Turquety, S., Baughcum, S. L., Ren, X., Fehsenfeld, F. C., Meagher, J. F., Spichtinger, N., Brown, C. C., McKeen, S. A., McDermid, I. S., and Leblanc, T.: Large upper tropospheric ozone enhancements above midlatitude North America during summer: in situ evidence from the IONS and MOZAIC ozone measurement network, J. Geophys. Res., 111, D24S05, doi:10.1029/2006JD007306, 2006.

Cooper, O. R., Trainer, M., Thompson, A. M., Oltmans, S. J., Tarasick, D. W., Witte, J. C., Stohl, A., Eckhardt, S., Lelieveld, J., Newchurch, M. J., Johnson, B. J., Portmann, R. W., Kalnajs, L., Dubey, M. K., Leblanc, T., McDermid, I. S., Forbes, G., Wolfe, D., Carey-Smith, T., Morris, G. A., Lefer, B., Rappenglück, B., Joseph, E., Schmidlin, F., Meagher, J., Fehsenfeld, F. C., Keating, T. J., van Curen, R. A., and Minschwaner, K: Evidence for a recurring Eastern North American upper tropospheric ozone maximum during summer, J. Geophys. Res., 112, D23304, doi:10.1029/2007JD008710, 2007.

Cummins, K., Murphy, M., Bardo, E., Hiscox, W., Pyle, R., and Pifer, A.: A combined TOA/MDF Technology upgrade of the US National Lightning Detection Network, J. Geophys. Res., 103, 9035-9044, 1998.

DeCaria, A. J., Pickering, K. E., Stenchikov, G. L., and Ott, L. E.: Lightning-generated $\mathrm{NO}_{\mathrm{x}}$ and its impact on tropospheric ozone production: A three-dimensional modeling study of a STERAO-A thunderstorm, J. Geophys. Res., 110, D14303, doi:10.1029/2004JD005556, 2005.

Dentener, F., Peter, W., Krol, M., van Weele, M., Bergamaschi, P., and Lelieveld, J.: Interannual variability and trend of $\mathrm{OH}$ and the lifetime of $\mathrm{CH}_{4}$ : 1979-1993 global chemical transport model calculations, J. Geophys. Res., 108, 4442, doi:10.1029/2002JD002916, 2003.

Fang, Y., Fiore, A. M., Horowitz, L. W., Levy, H., Hu, Y., and Russell, A. G.: Sensitivity of the $\mathrm{NO}_{\mathrm{y}}$ budget over the United States to anthropogenic and lightning $\mathrm{NO}_{\mathrm{x}}$ in summer, J. Geophys. Res., 115, D18312, doi:10.1029/2010JD014079, 2010.

Fehr, T., Höller, H., and Huntrieser, H.: Model study on production and transport of lightning-produced $\mathrm{NO}_{\mathrm{x}}$ in a EULINOX supercell storm, J. Geophys. Res., 109, D09102, doi:10.1029/2003JD003935, 2004.

Gilliland, A. B., Hogrefe, C., Pinder, R. W., Godowitch, J. M., Foley, K. L., and Rao, S. T.: Dynamic evaluation of regional air quality models: Assessing changes in ozone stemming from changes in emissions and meteorology, Atmos. Environ., 42, 5110-5123, 2008.

Grell, G., Dudhia, J., and Stauffer, D.: A description of the fifth generation Penn State/NCAR mesoscale model (MM5), NCAR Technical Note, NCAR/TN-398+STR, 1995.

Hansen, A. E., Fuelberg, H. E., and Pickering, K. E.: Vertical distributions of lightning sources and flashes over Kennedy Space Center, Florida, J. Geophys. Res., 115, D14203, doi:10.1029/2009JD013143, 2010.

Henderson, B. H., Pinder, R. W., Crooks, J., Cohen, R. C., Hutzell, W. T., Sarwar, G., Goliff, W. S., Stockwell, W. R., Fahr, A., Mathur, R., Carlton, A. G., and Vizuete, W.: Evaluation of simulated photochemical partitioning of oxidized nitrogen in the upper troposphere, Atmos. Chem. Phys., 11, 275-291, doi:10.5194/acp-11-275-2011, 2011.

Herron-Thorpe, F. L., Lamb, B. K., Mount, G. H., and Vaughan, J. K.: Evaluation of a regional air quality forecast model for tropospheric $\mathrm{NO}_{2}$ columns using the OMI/Aura satellite tropospheric $\mathrm{NO}_{2}$ product, Atmos. Chem. Phys., 10, 8839-8854, doi:10.5194/acp-10-8839-2010, 2010.

Hollingsworth, A., Engelen, R. J., Benedetti, A., Dethof, A., Flemming, J., Kaiser, J. W., Morcrette, J.-J., Simmons, A. J., Textor, C., Boucher, O., Chevallier, F., Rayner, P., Elbern, H., Eskes, H., Granier, C., Peuch, V.-H., Rouil, L., and Schultz, M. G.: Toward a monitoring and forecasting system for atmospheric composition: the Gems Project, B. Am. Meteor. Soc., 89, 1147-1164, doi:10.1175/2008BAMS2355.1, 2008.

Hudman, R. C., Jacob, D. J., Turquety, S., Leibensperger, E. M., Murray, L. T., Wu, S., Gilliland, A. B., Avery, M., Bertram, T. H., Brune, W., Cohen, R. C., Dibb, J. E., Flocke, F. M., Fried, A., Holloway, J., Neuman, J. A., Orville, R., Perring, A., Ren, X., Sachse, G. W., Singh, H. B., Swanson, A., and Wooldridge, P. G.: Surface and lightning sources of nitrogen oxides over the United States: Magnitudes, chemical evolution, and outflow, J. Geophys. Res., 112, D12S05, doi:10.1029/2006JD007912, 2007.

Huijnen, V., Eskes, H. J., Poupkou, A., Elbern, H., Boersma, K. F., Foret, G., Sofiev, M., Valdebenito, A., Flemming, J., Stein, O., Gross, A., Robertson, L., D'Isidoro, M., Kioutsioukis, I., Friese, E., Amstrup, B., Bergstrom, R., Strunk, A., Vira, J., Zyryanov, D., Maurizi, A., Melas, D., Peuch, V.-H., and Zerefos, C.: Comparison of $\mathrm{OMI} \mathrm{NO}_{2}$ tropospheric columns with an ensemble of global and European regional air quality models, Atmos. Chem. Phys., 10, 3273-3296, doi:10.5194/acp-10-3273-2010, 2010.

Huntrieser, H., Schumann, U., Schlager, H., Höller, H., Giez, A., Betz, H.-D., Brunner, D., Forster, C., Pinto Jr., O., and Calheiros, R.: Lightning activity in Brazilian thunderstorms during TROCCINOX: implications for $\mathrm{NO}_{\mathrm{x}}$ production, Atmos. Chem. Phys., 8, 921-953, doi:10.5194/acp-8-921-2008, 2008.

Huntrieser, H., Schlager, H., Lichtenstern, M., Roiger, A., Stock, P., Minikin, A., Höller, H., Schmidt, K., Betz, H.-D., Allen, G., Viciani, S., Ulanovsky, A., Ravegnani, F., and Brunner, D.: $\mathrm{NO}_{\mathrm{x}}$ production by lightning in Hector: first airborne measurements during SCOUT-O3/ACTIVE, Atmos. Chem. Phys., 9, 83778412, doi:10.5194/acp-9-8377-2009, 2009.

Jourdain, L., Kulawik, S. S., Worden, H. M., Pickering, K. E., Worden, J., and Thompson, A. M.: Lightning $\mathrm{NO}_{\mathrm{x}}$ emissions over the USA constrained by TES ozone observations and the GEOS-Chem model, Atmos. Chem. Phys., 10, 107-119, doi:10.5194/acp-10-107-2010, 2010.

Kain, J. S. and Fritsch, J. M.: Convective parameterization for mesoscale models: The Kain-Fritsch scheme, The representation of cumulus convection in numerical models, edited by: Emanuel, K. A. and Raymond, D. J., Amer. Meteor. Soc., 246 pp., 1993.

Kaynak, B., Hu, Y., Martin, R. V., Russell, A. G., Choi, Y., and Wang, Y.: The effect of lightning $\mathrm{NO}_{\mathrm{x}}$ production on surface ozone in the continental United States, Atmos. Chem. Phys., 8, 5151-5159, doi:10.5194/acp-8-5151-2008, 2008.

Koo, B., Chien, C.-J., Tonnesen, G., Morris, R., Johnson, J., Sakulyanontvittaya, T., Piyachaturawat, P., and Yarwood, G.: Natural emissions for regional modeling of background ozone and particulate matter and impacts on emissions control strategies, Atmos. Environ., 44, 2372-2382., doi:10.1016/j.atmosenv.2010.02.041, 2010.

Koshak, W. J., Solakiewicz, R. J., Blakeslee, R. J., Goodman, S. J., Christian, H. J., Hall, J. M., Bailey, J. C., Krider, E. P., Bateman, M. G., Boccippio, D. J., Mach, D. M., McCaul, E. W., Stew- 
art, M. F., Buechler, D. E., Petersen, W. A., and Cecil, D. J.: North Alabama Lightning Mapping Array (LMA): VHF source retrieval algorithm and error analyses, J. Atmos. Ocean. Tech., 21, 543-558, 2004.

Koshak, W. J., Peterson, H. S., McCaul, E. W., and Biazar, A.: Estimates of the lightning- $\mathrm{NO}_{\mathrm{x}}$ profile in the vicinity of the North Alabama Lightning Mapping Array, 21st International Lightning Detection Conference (ILDC)/Vaisala, 18-22 April 2010, Orlando, FL, United States, NASA Technical Report Document 20100021055, 2010.

Kunkrishnan, T. and Lawrence, M. G.: Sensitivity of $\mathrm{NO}_{\mathrm{x}}$ over the Indian Ocean to emissions from the surrounding continents and nonlinearities in atmospheric chemistry responses, Geophys. Res. Lett., 31, L15109, doi:10.1029/2004GL020210, 2004.

Lamsal, L. N., Martin, R. V., van Donkelaar, A., Celarier, E. A., Bucsela, E. J., Boersma, K. F., Dirksen, R., Luo, C., and Wang, Y.: Indirect validation of tropospheric nitrogen dioxide retrieved from the OMI satellite instrument: Insight into the seasonal variation of nitrogen oxides at northern midlatitudes, J. Geophys. Res., 115, D05302, doi:10.1029/2009JD013351, 2010.

Liu, X., Bhartia, P. K., Chance, K., Spurr, R. J. D., and Kurosu, T. P.: Ozone profile retrievals from the Ozone Monitoring Instrument, Atmos. Chem. Phys., 10, 2521-2537, doi:10.5194/acp-10-25212010, 2010.

Mach, D. M., Christian, H. J., Blakeslee, R. J., Boccippio, D. J., Goodman, S. J., and Boeck, W. L.: Performance assessment of the Optical Transient Detector and Lightning Imaging Sensor, J. Geophys. Res., 112, D09210, doi:10.1029/2006JD007787, 2007.

Martin, R. V., Jacob, D. J., Yantosca, R. M., Chin, M., and Ginoux, P.: Global and regional decreases in tropospheric oxidants from photochemical effects of aerosols, J. Geophys. Res., 108, 4097, doi:10.1029/2002JD002622, 2003.

Martin, R. V., Sauvage, B., Folkins, I., Sioris, C. E., Boone, C., Bernath, P., and Ziemke, J.: Space-based constraints on the production of nitric oxide by lightning, J. Geophys. Res., 112, D09309, doi:10.1029/2006JD007831, 2007.

Martini, M., Allen, D. J., Pickering, K. E., Stenchikov, G., Richter, A., Hyer, E., and Loughner, C.: The impact of North American anthropogenic emissions and lightning on long range transport of trace gases and their export from the continent during the summers of 2002 and 2004, J. Geophys. Res., 116, D07305, doi:10.1029/2010JD014305, 2011.

Metwally, M.: Jet aircraft engine emissions database development - 1992 military, charter, and nonscheduled traffic, NASA CR4684, NASA, Washington DC, 1995.

Napelenok, S. L., Pinder, R. W., Gilliland, A. B., and Martin, R. V.: A method for evaluating spatially-resolved $\mathrm{NO}_{\mathrm{x}}$ emissions using Kalman filter inversion, direct sensitivities, and spacebased $\mathrm{NO}_{2}$ observations, Atmos. Chem. Phys., 8, 5603-5614, doi:10.5194/acp-8-5603-2008, 2008.

National Acid Deposition program 2006 Annual Summary, NADP Data Report 2006-01, Illinois State Water Survey, University of Illinois at Urbana-Champaign, IL, 2006.

Novak, J. H. and Pierce, T. E.: Natural emissions of oxidant precursors, Water Air Soil Poll., 67, 57-77, 1993.

Orville, R. E., Huffines, R. E., Burrows, G. R., Holle, W. R., and Cummins, K. L., The North American Lightning Detection Network (NALDN)-first results: 1998-2000, Mon. Weather Rev., 130, 2098-2109, 2002.
Ott, L. E., Pickering, K. E., Stenchikov, G. L., Huntrieser, H., and Schumann, U.: Effects of lightning $\mathrm{NO}_{\mathrm{x}}$ production during the 21 July European Lightning Nitrogen Oxides Project storm studied with a three-dimensional cloud-scale chemical transport model, J. Geophys. Res., 112, D05307, doi:10.1029/2006JD007365, 2007.

Ott, L. E., Pickering, K. E., Stenchikov, G. L., Allen, D. J., DeCaria, A. J., Ridley, B., Lin, R.-F., Lang, S., and Tao, W.-K.: Production of lightning $\mathrm{NO}_{\mathrm{x}}$ and its vertical distribution calculated from three-dimensional cloud-scale chemical transport model simulations, J. Geophys. Res., 115, D04301, doi:10.1029/2009JD011880, 2010.

Petersen, W. A. and Rutledge, S. A.: On the relationship between cloud-to-ground lightning and convective rainfall, J. Geophys. Res., 103, 14025-14040, 1998.

Pierce, R. B., Schaack, T., Al-Saadi, J. A., Fairlie, T. D., Kittaka, C., Lingenfelser, G., Natarajan, M., Olson, J., Soja, A., Zapotocny, T., Lenzen, A., Stobie, J., Johnson, D., Avery, M. A., Sachse, G. W., Thompson, A., Cohen, R., Dibb, J. E., Crawford, J., Rault, D., Martin, R., Szykman, J., and Fishman, J.: Chemical data assimilation estimates of continental US ozone and nitrogen budgets during the Intercontinental Chemical Transport Experiment-North America, J. Geophys. Res., 112, D12S21, doi:10.1029/2006JD007722, 2007.

Rao, S. T., Galmarini, S., and Puckett, S.: Air Quality Model Evaluation International Initiative (AQMEII): Advancing state-of-science in regional photochemical modeling and its applications, B. Am. Meteor. Soc., 92, 23-30, doi:10.1175/2010BAMS3069.1, 2010.

Ren, X., Olson, J. R., Crawford, J. H., Brune, W. H., Mao, J., Long, R. B., Chen, Z., Chen, G., Avery, M. A., Sachse, G. W., Barrick, J. D., Diskin, G. S., Huey, L. G., Fried, A., Cohen, R. C., Heikes, B., Wennberg, P. O., Singh, H. B., Blake, D. R., and Shetter, R. E.: $\mathrm{HO}_{\mathrm{x}}$ chemistry during INTEX-A 2004: Observation, model calculation and comparison with previous studies, J. Geophys. Res., 113, D05310, doi:10.1029/2007JD009166, 2008.

Richter, A., Burrows, J. P., Nüß, H., Granier, C., and Niemeier, U.: Increase in tropospheric nitrogen dioxide over China observed from space, Nature, 437, 129-132, doi:10.1038/nature04092, 2005.

Sauvage, B., Martin, R. V., van Donkelaar, A., Liu, X., Chance, K., Jaeglé, L., Palmer, P. I., Wu, S., and Fu, T.-M.: Remote sensed and in situ constraints on processes affecting tropical tropospheric ozone, Atmos. Chem. Phys., 7, 815-838, doi:10.5194/acp-7-815-2007, 2007a.

Sauvage, B., Martin, R. V., van Donkelaar, A., and Ziemke, J. R.: Quantification of the factors controlling tropical tropospheric ozone and the South Atlantic maximum, J. Geophys. Res., 112, D11309, doi:10.1029/2006JD008008, 2007b.

Schumann, U. and Huntrieser, H.: The global lightning-induced nitrogen oxides source, Atmos. Chem. Phys., 7, 3823-3907, doi:10.5194/acp-7-3823-2007, 2007.

Singh, H. B., Brune, W. H., Crawford, J. H., Jacob, D. J., and Russell, P. B.: Overview of the summer 2004 Intercontinental Chemical Transport Experiment-North America (INTEX-A), J. Geophys. Res., 111, D24S01, doi:10.1029/2006JD007905, 2006.

Singh, H. B., Salas, L., Herlth, D., Kolyer, R., Czech, E., Avery, M., Crawford, J. H., Pierce, R. B., Sachse, G. W., Blake, D. R., Cohen, R. C., Bertram, T. H., Perring, A., Wooldridge, P. 
J., Dibb, J., Huey, G., Hudman, R. C., Turquety, S., Emmons, L. K., Flocke, F., Tang, Y., Carmichael, G. R., and Horowitz, L. W.: Reactive nitrogen distribution and partitioning in the North American troposphere and lowermost stratosphere, J. Geophys. Res., 112, D12S04, doi:10.1029/2006JD007664, 2007.

Sioris, C. E., Kurosu, T. P., Martin, R. V., and Chance, K.: Stratospheric and tropospheric $\mathrm{NO}_{2}$ observed by SCIAMACHY: first results, Adv. Space Res., 34, 780-785, 2004.

Skamarock, W. C., Klemp, J. B., Dudhia, J., Gill, D. O., Barker, D. M., Wang, W., and Powers, J. G.: A description of the advanced research WRF version 2, NCAR/TN-468+STR, 2005.

Smith, S. N. and Mueller, S. F.: Modeling natural emissions in the Community Multiscale Air Quality (CMAQ) ModelI: building an emissions data base, Atmos. Chem. Phys., 10, 4931-4952, doi:10.5194/acp-10-4931-2010, 2010.

SMOKE v2.6 User's Manual, The Institute for the Environment, University of North Carolina, available at: http://www. smoke-model.org/version2.6/SMOKE_v26_manual.pdf, 504 pp., 2009.

Tapia, A. J., Smith, A., and Dixon, M.: Estimation of convective rainfall from lightning observations, J. Appl. Meteorol., 37, 1497-1509, 1998.

Thompson, A. M., Stone, J. B., Witte, J. C., Miller, S. K., Pierce, R. B., Chatfield, R. B., Oltmans, S. J., Cooper, O. R., Loucks, A. L., Taubman, B. F., Johnson, B. J., Joseph, E., Kucsera, T. L., Merrill, J. T., Morris, G. A., Hersey, S., Forbes, G., Newchurch, M. J., Schmidlin, F. J., Tarasick, D. W., Thouret, V., and Cammas, J.P.: Intercontinental Chemical Transport Experiment Ozonesonde Network Study (IONS) 2004: 2. Tropospheric ozone budgets and variability over Northeastern North America, J. Geophys. Res., 112, D12S13, doi:10.1029/2006JD007670, 2007a.
Thompson, A. M., Stone, J. B., Witte, J. C., Miller, S. K., Oltmans, S. J., Kucsera, T. L., Ross, K. L., Pickering, K. E., Merrill, J. T., Forbes, G., Tarasick, D. W., Joseph, E., Schmidlin, F. J., McMillan, W. W., Warner, J., Hintsa, E. J., and Johnson, J. E.: Intercontinental Chemical Transport Experiment Ozonesonde Network Study (IONS) 2004: 1. Summertime upper troposphere/lower stratosphere ozone over Northeastern North America, J. Geophys. Res., 112, D12S12, doi:10.1029/2006JD007441, $2007 \mathrm{~b}$.

Tost, H., Jöckel, P., and Lelieveld, J.: Lightning and convection parameterisations - uncertainties in global modelling, Atmos. Chem. Phys., 7, 4553-4568, doi:10.5194/acp-7-4553-2007, 2007.

Vukovich, J. M. and Pierce, T.: The implementation of BEIS3 within the SMOKE modeling framework, available at: http://www.epa.gov/ttn/chief/conference/ei11/modeling/ vukovich.pdf, 2002.

Zhang, R., Tie, X., and Bond, D. W.: Impacts of anthropogenic and natural $\mathrm{NO}_{\mathrm{x}}$ sources over the US on tropospheric chemistry, P. Natl. Acad. Sci. USA, 100, 1505-1509, doi:10.1073/pnas.252763799, 2003.

Zhao, C., Wang, Y., Choi, Y., and Zeng, T.: Summertime impact of convective transport and lightning $\mathrm{NO}_{\mathrm{x}}$ production over North America: modeling dependence on meteorological simulations, Atmos. Chem. Phys., 9, 4315-4327, doi:10.5194/acp-9-43152009, 2009. 